This PDF is a selection from a published volume from the National Bureau of Economic Research

Volume Title: Social Security Programs and Retirement around the World: Fiscal Implications of Reform

Volume Author/Editor: Jonathan Gruber and David A. Wise, editors

Volume Publisher: University of Chicago Press

Volume ISBN: 0-226-31017-5; 978-0-226-31017-6

Volume URL: http://www.nber.org/books/grub07-1

Publication Date: October 2007

Title: Fiscal Implications of Pension Reforms in Italy

Author: Agar Brugiavini, Franco Peracchi

URL: http://www.nber.org/chapters/c0056 


\section{Fiscal Implications of Pension Reforms in Italy}

Agar Brugiavini and Franco Peracchi

\subsection{Introduction}

Italy has seen a flurry of reforms during the 1990s, and economists and policymakers are still struggling to assess their immediate results as well as their long-term effects. Many analysts argue that the overall design of the recent Italian reforms is probably good, yet more steps need to be taken to speed up the reform process and reap the benefits, which, due to the adverse demographic trends, could easily evaporate.

In this chapter, we contribute to the current debate on the Italian pension system by analyzing the impact of social security reforms, in terms of both their budgetary implications and their distributional effects. This is done by simulating the effects of three hypothetical reforms, plus the effects of the 1995 reform of the Italian pension system (the so-called Dini reform). Our approach relies on the use of a semistructural econometric model to predict retirement probabilities under different policy scenarios, so as to properly take into account the behavioral effects of the reforms. On the basis of the estimated retirement model, we develop a complete accounting exercise that includes not only changes in gross future benefits due to policy changes, but also changes in social security contributions, income taxes, and value-added taxes. Thus, our results provide not only estimates of the workers' gains or losses, but also an exhaustive evaluation of the gains and losses for the government budget.

We find that the reforms, particularly the Dini reform (once fully phased in), have a substantial impact on individuals' retirement decisions and 
their net social security wealth, as well as substantial gains for government finances.

\subsection{An Overview of the Italian Pension System and Its Reforms}

Before turning to the analysis of different social security reforms, it is useful to briefly describe the reform process that has taken place in Italy, and the recent developments in the political arena. The growing concern of the European Union (EU) with meeting the targets imposed by the Stability and Growth Pact has stimulated a debate on the effects of the recent reforms and the need for further reforms. It should be mentioned that Italy, along with the other member states of the EU, committed itself to a fiveyear increase of the effective retirement age by the year 2010. Specific targets have also been set on participation rates of older workers.

Many argue that the changes introduced during the 1990s may be inadequate in the light of future demographic trends, and that it is imperative to raise the effective retirement age. Empirical work carried out on the issue shows that there is a strong relationship between the tax incentives to retire and the age at which men are observed to actually retire in different countries. ${ }^{1}$ For Italy, we still observe a substantial number of early retirees. ${ }^{2}$ Therefore, an evaluation of the impact and efficacy of the reforms, which has already started with the 2001 Ministerial Committee ${ }^{3}$ appointed by the Italian Welfare Ministry, is of crucial importance.

The reforms of the 1990s have tackled several aspects of the Italian social security system, but three are particularly relevant: (1) benefit computation rules, (2) indexation rules, and (3) retirement age and eligibility criteria. ${ }^{4} \mathrm{It}$ is useful to recall that the vast majority of the population is insured with the National Institute for Social Security (INPS), and since this chapter focuses attention on the most important fund administered by the INPS, the Private Sector Employees Fund (FPLD), our description of the reforms will mainly focus on the changes affecting private sector employees.

A first reform (known as the Amato reform) was passed by Parliament in 1992. Once phased in, it would reduce pension outlays and iron out major differences between various sectors and occupations. However, this reform only marginally changed the rules governing early retirement and, according to many, did not produce the much-needed savings in the budget. Hence the second reform (the so-called Dini reform) of 1995. This reform totally

1. The concept of an implicit tax was introduced by Gruber and Wise (1999).

2. See Brugiavini and Peracchi (2004) and Brugiavini, Peracchi, and Wise (2003).

3. Relazione Finale della Commissione Ministeriale di "Verifica del sistema previdenziale ai sensi della legge 335/95 e successivi provvedimenti, nell'ottica della competitività, dello sviluppo e dell'equità."

4. For a description of the Italian social security system before 1992, see Brugiavini (1999), Brugiavini and Peracchi (2004), and Franco (2002). 
changed some of the basic rules for granting benefits to future retirees, and tried to harmonize the actuarial rates of return for early and late retirees. Table 6.1 summarizes some of the key features of three regimes: the regime prevailing before the Amato reform (denoted as pre-1993 regime), the one prevailing during the transition (currently in place), and the one prevailing with the Dini reform fully in place (post-1995 regime). However, both the Amato and the Dini reforms are characterized by a very long transitional period affecting all cohorts of post-1992 retirees: the provisions for the transitional periods involve a pro rata method of establishing eligibility and benefit computation criteria on the basis of seniority.

\subsubsection{The Dini Reform and Recent Assessments of the Reform Process}

The Dini reform adopts a notionally defined-contribution method of benefit calculation. The initial pension amount is the annuity equivalent to the present value (at retirement) of past payroll taxes, capitalized by means of a five-year moving average of nominal GDP growth rates. The relevant payroll tax rate is 33 percent, and an age-related actuarial adjustment factor is applied to the resulting figure. ${ }^{5}$ In this case, too, capping is applied on the present value of contributions, rather than on pensionable earnings. The 1995 reform introduced — at the steady state — a window of pensionable ages with an associated actuarially based adjustment of pensions. This window spans age 57 to 65 , with actuarial adjustment factors of 4.720 percent and 6.136 percent, respectively. These coefficients make the present value of future benefits equal to capitalized contributions for people with survival probabilities equal to those in the 1990 life tables. They should be revised every ten years on the basis of changes in life expectancy and a comparison of the rates of growth of GDP and taxable earnings. It should be noted that, even at the steady state, the system will not achieve complete age-neutrality, given the mortality prospects of Italian workers. ${ }^{6}$

Minimum contribution requirements changed from the initial fifteen years to just five years after 1995, while payroll taxes increased to 32.7 percent of gross earnings (to be split between employer and employee), up from approximately 27 percent in 1995 .

The implementation of the reform was (and still is) extremely gradual. Workers with at least eighteen years of contributions in 1995 will receive a pension computed on the basis of the rules applying before 1992. Those with less than eighteen years of contributions in 1992 will be subject to a pro rata regime: the 1995 reform will apply only to the contributions paid after $1995 .^{7}$ Only individuals who began working after 1995 will receive a

5. Hence the benefit is: 33 percent $\times$ adjustment factor $\times$ present value of SS taxes.

6. See Barbi (2001).

7. The benefits paid to individuals in the pro rata regime will be computed on the basis of two components: the pre-1995 contributions and the contributions paid from 1995 onward. 


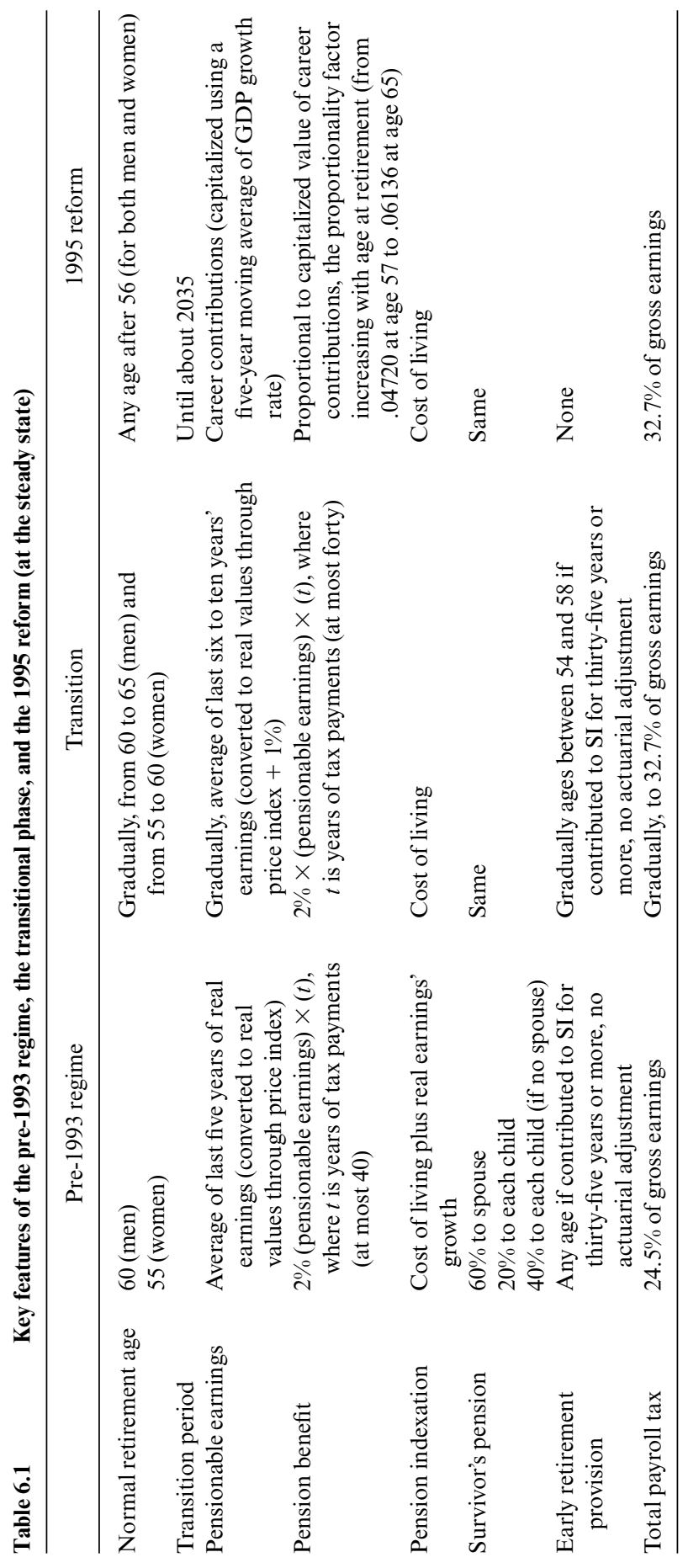


pension computed only on the basis of the new rules. Hence the length of the transition phase, as well as other aspects of the reform, may significantly reduce its expected benefits.

A first round of evaluations of the reforms became available throughout the 1990s. Some of these evaluations were based on generational accounting. For example, it was estimated that in order to ensure the long-term sustainability of public finances, a 5 percent increase in taxes paid by all generations would be required. Without the pension reforms introduced in the 1990s, the required tax increase would have been 9 percent. About 40 percent of those employed in 1999 could fully retire under the pre-1992 regime. For these people, the incentive to retire early was actually increased by expectations that the retirement conditions might be tightened (Franco 2002).

The Report of the Ministerial Committee (2001) shows that the savings obtained between 1996 and 2000 were essentially due to changes in the indexation rules and curtailing early retirement. The difficulty in building a complete evaluation model that incorporates behavioral responses to the reforms relies on the availability of good data and on the overall approach. Brugiavini and Peracchi (2004) provide an econometric model that focuses on dynamic incentives but does not address fiscal implications, while other recent studies ${ }^{8}$ carry out accounting exercises that neglect the impact of policy changes on the retirement decisions of individuals.

\subsection{The Retirement Model}

The simulation exercise carried out in the present chapter relies on an econometric model of the retirement decisions of Italian workers based largely on the work of Gruber and Wise (2004) and already applied to the Italian case by Brugiavini and Peracchi (2004). In the present chapter, we limit our description of the econometric work to the main features of our modeling strategy and to the data. An important difference with respect to Brugiavini and Peracchi (2004) is the fact that the availability of a new release of the data, characterized by a larger sample size, allows us to follow a novel approach. Therefore, the underlying empirical work also deserves attention.

\subsubsection{The Data}

The retirement decision is analyzed through a reduced-form model, estimated on a random sample of administrative records from the Istituto Nazionale di Previdenza Sociale (INPS) archives. ${ }^{9}$ The sample is drawn

8. See Ministero dell'Economia (Ragioneria Generale dello Stato) 2001 and ForneroCastellino 2001.

9. This is a subsample of workers born either on March 1st or on October 1st of any possible year contained in the archive. 
from the so-called INPS Workers-Archive (Archive O1M), which contains records on all private sector employees insured with INPS. The information on each employee is entered by the employer on a standard form. Our data consists of a random sample of about 200,000 workers entering the archive at any time during the period 1973-1997, and was followed continuously until they leave the sample. Employment spells can last any number of years, and individuals who leave the sample may enter again in any subsequent year. The panel is therefore highly unbalanced.

The main advantages of using these data are that they span a fairly long time period and contain information on gross earnings, which form the basis for the calculation of social security benefits. However, there are several shortcomings.

1. The dataset only covers private sector employees, leaving out public sector employees and the self-employed. Even for private sector employees, however, coverage is not full, and a small fraction of them is not included.

2. The reason a worker drops off the archive is not known: in addition to retiring, workers could die, become self-employed or public sector employees, or simply stop working.

3. Important covariates (e.g., education level, spousal information, and other family background variables) are missing. As a result, we have very few demographic controls available, we do not know about marital status, and we cannot say much about differential mortality.

4. There is no information on receipt of disability or other types of benefits.

The initial sample selection is as follows. We focus on workers between 18 and 70 years of age who work at least 28 days a year. We exclude from the analysis workers belonging to special INPS funds (nursery-school teachers, local authorities employees, etc.). ${ }^{10}$

\subsubsection{Earnings Projection and Transitions to Retirement}

The specification of a model for the age-earnings profile represents an essential step in the estimation of social security wealth at the individual level. This is especially important in Italy, as the process of social security reform involves moving from a final salary type of benefit formula (pre1993 system) to a formula based on the value of lifetime contributions (1995 reform). ${ }^{11}$ In the following we describe additional hypothetical reforms, which also involve extending the benefit calculation period.

10. We could include these observations to add variability across funds, but these workers represent only a small number (less than 100 observations) and tend to exhibit many gaps in their careers.

11. In this and in the following sections we only describe results for the 1995 reform (results for the other cases are available on request from the authors). 
In order to estimate earnings profiles and eventually measure social security wealth, we further select the sample by including only workers who are present in the sample for an uninterrupted period of at least five years (workers often appear for one year and then disappear from the sample for a long spell). The five-year minimum requirement is activated by the fact that this corresponds to the minimum contributive period under the 1995 reform. We only keep workers who do not have substantial gaps (more than ten years missing) in their records. This is because we cannot say whether in that time span they were engaged in other labor market or nonlabor market activities (such as maternity leaves, or undertaking further education). The choice of a ten-year interval is arbitrary, and is based on a preliminary inspection of the data. ${ }^{12}$

The information available to model age-earnings profiles in the INPS sample is somewhat limited, for it consists only of age, gender, occupation, sector of employment, and region of working activity. ${ }^{13}$

The earnings-modeling strategy is as follows: individual real ageearnings profiles are modeled with individual fixed effects in order to fill gaps of one or two years in workers' careers. The earnings profile is assumed to be completely flat after the last year of observed earnings. This corresponds to the assumption that, at the individual level, the real earnings process is a random walk, with no drift. In practice, the jump-off point for the earnings projections is taken to be the average of the last three years of observed earnings. This jump-off point pins down the level of the ageearnings profile for each individual. ${ }^{14}$ Note that this might lead to underestimating future earnings growth, particularly for younger cohorts. However, since our "sample at risk" (as defined in the following) consists mainly of older cohorts, the problem may not be too severe. ${ }^{15}$ Furthermore, for

12. It should be noted that in order to gain variability in social security benefits, we did experiment with a larger sample that included almost all workers, regardless of the existence of gaps in their careers. However, this did not add valuable information, as the majority of workers with substantial spells out of the private sector would end up qualifying for minimum benefits (the level of which is fixed by legislation each year) or for an old-age income guarantee (pensione sociale). Hence there would be very little correlation between earnings histories and pension benefits for these individuals, and the effects of potential reforms in changing the incentives to retire would be negligible (these workers would basically qualify for the minimum benefit under all regimes). Therefore these cases would end up blurring the results rather than adding variability to be exploited. Finally, our choice of the ten years' threshold and the requirement of a minimum of five years' presence in the archive give us an estimated sample percentage of minimum benefit recipients that is not too far from what was observed in the universe of pension awards as recorded by the INPS Administration.

13. This is actually the region where the firm is located. Hence a comparison with the SHIW and national accounts data reveals that there seems to be a higher number of workers located in the northwest, where many large firms have their headquarters.

14. When going backward, the jump-off point corresponds to the average of the first three observations available for each individual.

15. The cohorts at risk are defined according to year of birth: for the oldest cohort these are between 1918 and 1926, for the next cohort 1927-36, and for the youngest cohort, 1937-44. 
those above 50, earnings are lower on average and are very noisy, possibly because of part-time work or the coexistence of early retirement benefits and working activities. If one looked backward, using a flat earnings profile would grossly overestimate the level of earnings at earlier ages and grossly underestimate real earnings growth. To avoid this problem, individual earnings are assumed to grow at the annual growth rate of aggregate earnings, for the years when this information is available, and at a constant real rate of 1.5 percent otherwise. ${ }^{16}$

Notice that, although our first data point is in 1973, we need to go back to the 1930s for some of our workers in order to complete their working history. Hence, we are forced to use a procedure that makes use of aggregate growth rates when projecting backward into the distant past. Also, in projecting earnings forward, individuals are assumed to form expectations by using the model. In other words, for each age we only use actual earnings up to that age, and project earnings from that age forward according to the forecasting model.

Our data contain no information on the reasons why workers leave the archive. Thus, in order to use the data, we make the strong assumption that every exit from the archive is due to retirement. In fact, rather than retiring, a worker could have died, or moved from private sector employment to public sector employment or to self-employment. Our identifying assumption is that, over the range of ages that we consider (age 50 to 65), exit from the INPS archive is due to retirement, not to other reasons. This assumption is not in contrast with what we observe in an alternative sample provided by the Bank of Italy (Survey of Household Income and Wealth [SHIW]), where we have the full set of information available concerning the occupational status of individuals in each year. ${ }^{17}$ As for mortality, in the simulation we purge the exits of the component that can be attributed to differential mortality by age, sex, and cohort.

For Italian workers, the only relevant alternative escape route from the labor force is disability. Although other bridging plans exist, they would all fall in the category of preretirement or early retirement and, in our data, would effectively correspond to retirement. We argue that exits via disability are not particularly relevant to our sample because, after the changes legislated in 1984, the importance of this escape route has greatly diminished and, in the age range that we consider (50 to 70), the number of disability pensions is negligible relative to old-age pensions. ${ }^{18}$

16. Aggregate earnings are equal to the earnings series put together by Rossi, Sorgato, Toniolo (1993) for the years before 1970 and to national account statistics for subsequent years up to 1999.

17. In the SHIW sample, different definitions of pensioner are available, based on selfreported occupational status, on earnings, and on benefits receipts. However, no marked difference in the distribution of retired people by age emerged from adopting different definitions.

18. See Brugiavini and Peracchi (2004) for a more detailed discussion. 


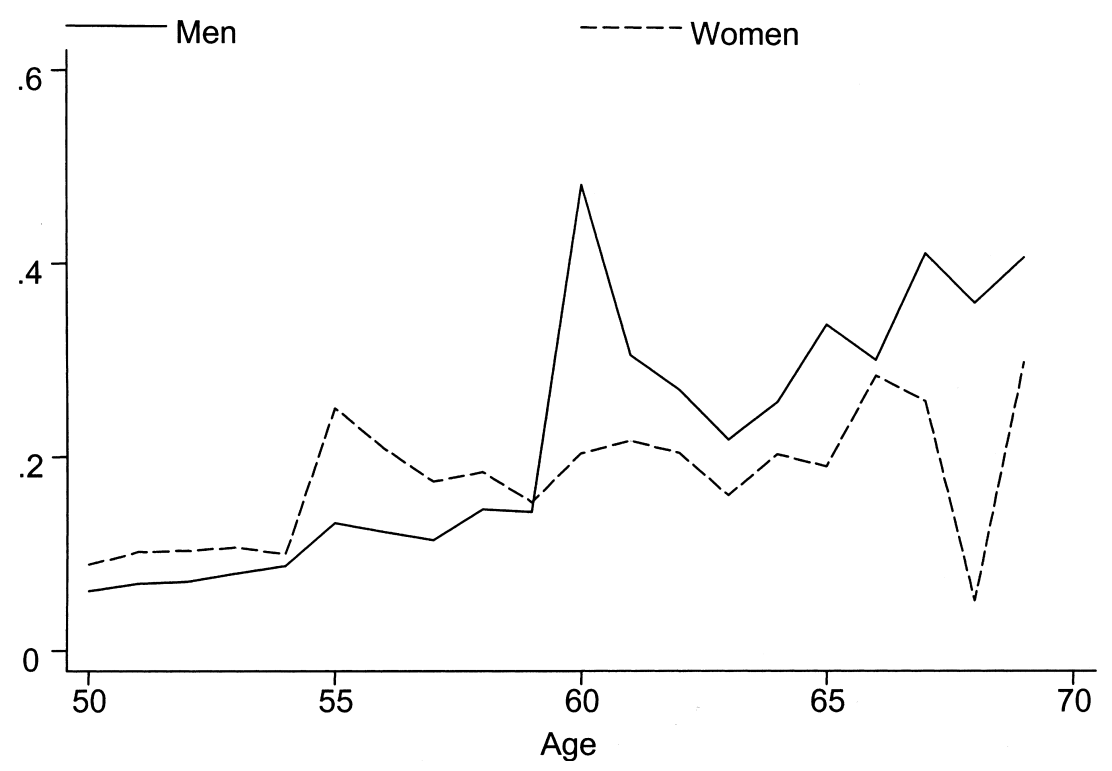

Fig. 6.1 Empirical hazard from the INPS sample

Figure 6.1 presents the nonparametric retirement hazard based on the INPS sample for men and women. For men there is an important spike at age 60 , but the hazard is not flat at younger ages, whereas for women there are several important ages at which the conditional probability of leaving the labor force peaks.

\subsubsection{Definition of Social Security Wealth and Incentive Measures}

Key elements of our econometric model are the concepts of social security wealth and related dynamic incentives. It is useful to briefly recap these concepts.

For a worker of age $a$, we define social security wealth (SSW) in case of retirement at age $h \geq a$ as the expected present value of future pension benefits

$$
S S W_{h}=\sum_{s=h+1}^{S} \rho_{s} B_{s}(h),
$$

where $S$ is the age of certain death (110 years), $\rho_{s}=\beta^{s-a} \pi_{s}$ is a discount factor that depends on the rate of time discount $\beta$ and the survival probability $\pi_{s}$ at age $s$ conditional on being alive at age $h$, and $B(h)$ is the pension benefit expected at age $s \geq h+1$ in case of retirement at age $h$. Pension benefits are the net of income taxes. Given SSW, we define three incentive measures for a worker of age $a$. 
1. Social security accrual (SSA) is the difference in SSW due to postponing retirement from age $a$ to age $a+1$.

$$
S S A_{a}=S S W_{a+1}-S S W_{a}=\sum_{s=a+2}^{S} \rho_{s}\left[B_{s}(a+1)-B_{s}(a)\right]-\rho_{a+1} B_{a+1}(a) .
$$

The SSA is negative if the expected present value of pension benefits forgone by postponing retirement by one year is greater than $\sum_{s=a+2}^{S} \rho_{s}\left[B_{s}(a+\right.$ 1) $-B_{s}(a)$ ], the expected present value of the increment in the flow of future pension benefits. The rescaled negative accrual $\tau_{a}=-S S A_{a} / W_{a+1}$, where $W_{a+1}$ are expected net earnings at age $a+1$ based on the information available up to age $a$, is called the implicit tax/subsidy of postponing retirement from age $a$ to age $a+1$.

2. Peak value: $\mathrm{PV}_{a}=\max _{h}\left(S S W_{h}-S S W_{a}\right), h=a+1, \ldots, R$, where $R$ is the mandatory retirement age (the latter does not exist in Italy, but given the retirement evidence we find it reasonable to put $R=70$ ). Thus, the peak value is the maximum difference in SSW between retiring at future ages and retiring at the current age.

3. Option value: $\mathrm{OV}_{a}=\max _{h}\left(V_{h}-V_{a}\right), h=a+1, \ldots, R$, where

$$
V_{a}=\sum_{s=a+1}^{S} \rho_{s}\left[k B_{s}(h)\right]^{\gamma}
$$

is the intertemporal expected utility of retiring at age $a$, while

$$
V_{h}=\sum_{s=a+1}^{h} \rho_{s} W_{s}^{\gamma}+\sum_{s=h+1}^{S} \rho_{s}\left[k B_{s}(h)\right]^{\gamma}
$$

is the intertemporal utility of retiring at age $h>a$. Thus, the option value is the maximum utility difference between retiring at future ages and retiring at age $a$. We parameterize the model by assuming $\gamma=1$ and $k=1.25$. Under these assumptions, $V_{a}=1.25 S S W_{a}$ and

$$
V_{h}=\sum_{s=a+1}^{h} \rho_{s} W_{s}^{\gamma}=1.25 S S W_{h} .
$$

If expected earnings are constant at $W_{a}$ (as assumed in our earnings model), then

$$
V_{h}-V_{a}=W_{a} \sum_{s=a+1}^{h} \rho_{s}+1.25\left(S S W_{h}-S S W_{a}\right) .
$$

That is, the peak value and the option value are proportional to each other, except for the effect due to the term $\sum_{s=a+1}^{h} \rho_{s}$.

In the actual calculation of SSW, we assume a time discount factor of 1.5 percent $(\beta=.985)$. Benefits are defined in real terms, and the indexation rules prevailing under each legislation are implemented (e.g., in the baseline we apply indexation to both price inflation and real wages). We also 
assume that real earnings growth after 1997 (the last year of the INPS sample) is constant at 1.5 percent.

Estimation of SSW is carried out separately for men and women. Household social security wealth is set equal to the man's social security wealth when the wife does not work. In estimating the model, we must deal with the fact that the actual age of entry into the labor market is not always known. We used the information on the initial occupational level to get a reasonable proxy for educational attainments. This is then used to impute an initial age for a worker's contributive history.

Eligibility and benefit computation rules prevailing under each regime are rather complex (see section 6.2), and some shortcuts were made. Finally, we computed social security wealth net of income tax, by subtracting income tax from gross pension benefits.

\subsubsection{The Reduced-Form Retirement Model: Methodology and Estimation Results}

In this section, we present the results of modeling exit into retirement using probit models that include, in addition to a standard set of covariates (such as age, occupation, and sector of employment), the incentive measures discussed in the previous section.

The response variable is a binary indicator, representing exit from the INPS sample between the year $t$ and the year $t+1$. The population at risk consists of workers aged between 50 and 70 in any of the relevant years. The sample used for estimation includes all consecutive pairs of years from 1980 to 1981 through 1996 to 1997 . We restrict the analysis to individuals at risk after 1980. The reason is twofold: first, it is very hard to capture the behavior of workers, taking into account all of the institutional changes affecting the various cohorts over a long time span. The period 1980-1992 has the advantage of being relatively stable in terms of policy changes. Second, because in some cases we have to model earnings profiles going back fifty years, given the existing limitations on aggregate wage data it is reasonable to limit the time horizon to recent years. In this way, our oldest worker is aged 70 in 1980, and we only need to back-cast earnings to the year $1930 .{ }^{19}$

The social security regime is assumed to be the transitional one introduced in 1992 (see table 6.1). This is the relevant regime for the workers in our sample, who would not yet experience the changes introduced by the 1995 reform through the sample period. Overall, using the pre-1993 rules would lead to negligible differences in terms of social security wealth and

19. Retirement is not mandatory. Given that we assume an individual at risk up to age 70 , and given that we cannot exclude that she or he started working at age 20, we cannot rule out the possibility that this individual worked for fifty years. 
eligibility. This is because, as already mentioned, the rights of workers near retirement were changed only marginally by the 1992 reform: according to seniority, most workers at risk would fully retire under the pre-1993 rules.

For each incentive measure, two basic specifications are considered, for a total of six estimated models. The incentive variables are the accrual, the peak value, and the option value, whereas the dependence of the retirement hazard on age is modeled either through a simple linear age term or through a full set of age dummies. All specifications include a set of sectoral and regional indicators and a set of earnings measures relevant for the retirement choice. Different from our previous work, and from other countries that contribute to this project, we only use two resource measures, capturing, respectively, the level of social security wealth and the trade-off between benefits and labor earnings: net social security wealth and pensionable earnings. ${ }^{20}$ The additional variable, measuring future earnings, which we included in previous studies, is left out, because in the Italian case a multicollinearity problem emerges under the baseline and the transitional period. ${ }^{21}$ The problem is caused by the way benefits are computed: pensionable earnings, which form the basis of our social security wealth estimate, are equal to average earnings in the last five years, and in many cases they take the same value of (or a very close value to) one-stepahead projected earnings.

Results for the specification with age dummies are summarized in table 6.2: each column refers to a particular incentive variable and we report only the estimated coefficients of the variables of interest. It should be noted that our purpose here is not to produce a good fit, but rather to create a basis for the simulation exercise by adopting a parsimonious specification..$^{22}$ The use of age dummies increases the fit relative to the model with a linear age term, but only marginally. This suggests that age is an important determinant of retirement decisions but, despite the presence of spikes in the hazard, we obtain only marginal gains by making use of a fully parameterized model. Hence, these spikes may be less important than first appears in explaining the age-retirement process, as most of the movement comes from the exits taking place between age 50 and age 60 . As shown in table 6.2, the social security wealth variable and the incentive variables have, by and large, the correct sign: of the three incentive variables, the accrual and option value have the correct sign and are significantly different from zero.

20. To be more precise, we use a quadratic polynomial in pensionable earnings. All continuous variables enter in the form of deviation from the mean.

21. For brevity, we do not report the estimates of regressions of the future earnings variable against social security wealth, pensionable earnings, and all the relevant covariates. This regression shows the clear symptoms of multicollinearity; for example, an extremely high $t$-statistics for the two variables under investigation.

22. For example, if we used year-of-birth cohorts, results improve dramatically. 
Probit models of retirement decisions (with age dummies)

\begin{tabular}{|c|c|c|c|c|c|c|}
\hline & \multicolumn{2}{|c|}{ Accrual } & \multicolumn{2}{|c|}{ Peak value } & \multicolumn{2}{|c|}{ Option value } \\
\hline & $\begin{array}{l}\text { Estimated } \\
\text { coefficient }\end{array}$ & $\begin{array}{l}\text { Standard } \\
\text { error }\end{array}$ & $\begin{array}{l}\text { Estimated } \\
\text { coefficient }\end{array}$ & $\begin{array}{l}\text { Standard } \\
\text { error }\end{array}$ & $\begin{array}{l}\text { Estimated } \\
\text { coefficient }\end{array}$ & $\begin{array}{l}\text { Standard } \\
\text { error }\end{array}$ \\
\hline \multicolumn{7}{|c|}{ Male: 20,092 observances } \\
\hline $\begin{array}{l}\text { Social security } \\
\text { wealth }\end{array}$ & 0.00058 & 0.00025 & 0.00060 & 0.00028 & 0.00027 & 0.00028 \\
\hline Incentive & -0.00103 & 0.00065 & -0.00031 & 0.00063 & -0.00099 & 0.00036 \\
\hline Constant & -1.29995 & 0.04415 & -1.32031 & 0.04738 & -1.27715 & 0.04400 \\
\hline$R^{2}$ & \multicolumn{2}{|c|}{0.0836} & \multicolumn{2}{|c|}{0.0835} & \multicolumn{2}{|c|}{0.0840} \\
\hline Log-likelihood & \multicolumn{2}{|c|}{-7054.7301} & \multicolumn{2}{|c|}{-7055.8927} & \multicolumn{2}{|c|}{-7052.1504} \\
\hline \multicolumn{7}{|c|}{ Female: 5,165 observances } \\
\hline $\begin{array}{l}\text { Social security } \\
\text { wealth }\end{array}$ & 0.00063 & 0.00083 & 0.00157 & 0.00094 & 0.00002 & 0.00097 \\
\hline Incentive & -0.00480 & 0.00474 & 0.00443 & 0.00312 & -0.00210 & 0.00137 \\
\hline Constant & -1.18974 & 0.06768 & -1.209801 & 0.06881 & -1.15935 & 0.07085 \\
\hline$R^{2}$ & \multicolumn{2}{|c|}{0.0314} & \multicolumn{2}{|c|}{0.0316} & \multicolumn{2}{|c|}{0.0317} \\
\hline Log-likelihood & \multicolumn{2}{|c|}{-2029.3559} & \multicolumn{2}{|c|}{-2028.872} & \multicolumn{2}{|c|}{-2028.6804} \\
\hline
\end{tabular}

\subsection{Simulating Policy Changes}

The aim of this section is to simulate the total fiscal implications of pension reforms. The hypothetical reforms, described later, contain some useful elements for the debate currently taking place in Italy. For example, the reform that we indicate as "actuarial adjustment" represents a change of the current Italian system in line with what many experts and policy makers advocate. We also simulate the steady-state effects of the actual reform introduced in 1995 (the so-called Dini Reform).

\subsubsection{Social Security Regimes}

The baseline or reference regime $(R 0)$ is the social security system prevailing before 1992; the various successive regime changes are evaluated against this regime. ${ }^{23}$ As for the reforms considered, a brief description is useful.

\section{R1: Three-Year Reform}

This reform preserves all the features of the system but increases by three years the normal retirement age. Since in Italy all ages before the normal

23. As we already pointed out, the econometric model that predicts retirement is estimated on the sample of workers observed between 1974 and 1997, hence experiencing the transitional period. In the estimation, we evaluate social security wealth and the incentive variables according to the rules of the transitional phase, because these are the incentives actually faced by individuals. However, in the simulation we look at changes occurring between steady states. 
retirement age are potentially an early retirement age (conditional on seniority), the entire hazard is effectively shifted by three years. The seniority rule is preserved in its original format (see also table 6.1).

\section{R2: Actuarial Reform}

This reform should achieve an actuarially fair system without changing any other feature of the program (i.e., no change in basic benefit calculation rules, in means testing and eligibility to minimum benefits, and in indexation). The normal retirement age is the same as the base case, and the rules in place are unchanged at that age (hence, the replacement ratio is the same at that age). The reform introduces an actuarial adjustment of 6 percent for each year past the normal retirement age. Thus, benefits becoming available before the normal retirement age are reduced by 6 percent per year, while benefits becoming available after the normal retirement age are increased by 6 percent per year.

\section{R3: Common Reform}

This reform is common to all countries considered in this volume. The crucial feature is that, different from the other cases, this reform envisages an ideal system, the same for all countries, which represents a complete departure from the systems currently in place in many countries (Italy is one example). This simulation features an early retirement age of 60 and a normal retirement age of 65 . It provides a retiree with a benefit that replaces 60 percent of her or his projected earnings when she or he turns 65. It applies an actuarial reduction of 6 percent per year for early claiming and an actuarial increase of 6 percent per year for later claiming. It essentially makes early retirement costly and introduces age neutrality in retirement choices.

\section{R4: The 1995 Reform}

The 1995 reform adopts a notionally defined contribution method of benefit calculation. The initial pension amount is the annuity equivalent to the present value (at retirement) of past payroll taxes, capitalized by means of a five-year moving average of the nominal GDP growth rate. The value of the annuity is an increasing function of the age at retirement. It is equal to 4.72 percent of the present value of past payroll taxes for people retiring at age 57, and to 6.136 percent for people retiring at age 65 or older. ${ }^{24} \mathrm{Cap}-$ ping is applied (on the present value of contributions, rather than on pensionable earnings).

\subsubsection{Simulation Methodology}

For each of the five policies described previously (four regime changes plus the baseline) and for each worker in our final sample, we estimate the

24. Hence the benefits is: 33 percent $\times$ adjustment factor $\times$ present value of SS taxes. 
social security wealth variable and the incentive measures. For each worker we also observe a number of covariates, such as age, occupational status, and so on. We simulate retirement decisions of these workers on the basis of the econometric model described in section 6.3, using the social security wealth variable and the incentive measures specific to each regime. All other covariates are identical across simulations. In this way, retirement probabilities change in response to changes in the policy variables according to the estimated parameters (shown also in table 6.2). However, a few adjustments are needed in order to adapt the estimates to the policy environment. One of these adjustments concerns the age dummies. To recap, we make use of two econometric models: one where age enters linearly and is not affected by the reform changes (S1), and one where age enters through a set of age dummies (S3). The coefficients on the age dummies of this model are bound to be affected by the reforms, over and above the changes implied by any modification in eligibility rules. For example, in Italy, the hazard for men has a spike at age 60 , which is the normal retirement age for men under the baseline $(R 0)$. If the normal retirement age is shifted by three years (regime $R 1$ ), then the age effect observed at age 60 should be felt at age 63, and the whole hazard should reflect the policy change.

Simulations are carried out in two steps: the first step generates retirement probabilities under the different scenarios, whereas the second step computes the fiscal implications of the changes. In order to carry out the exercise, we initially focus on a homogeneous group of workers by drawing a simulation sample of 699 individuals (men and women) born in 1938, 1939, and 1940 from the original INPS sample. ${ }^{25}$ We disregard time differences between these three cohorts and simply assume everybody to be age 50 in 1990. For these individuals, we have all the relevant information for all ages between 50 and 70; that is, we follow them through these ages even if some of them have effectively retired in the original sample. The intuition behind this procedure is to compute the direct fiscal effects of the reforms (the mechanical effects) and the fiscal effects due to changes in retirement behavior (the behavioral effects) as seen from the perspective of an individual who reaches age 50 in 1990 and is considering whether to retire at any future age.

\subsubsection{Basic Assumptions}

Unlike most other countries in this project, we assume that men are married to women who do not work, while working women are single. Hence, social security wealth of men can be thought of as a household's social security wealth (men are head of the household). This assumption is introduced cohort. 
because our data contain no information on workers' marital status, and in the Italian legislation the only major difference between a single worker and a married worker is eligibility to survivors' pension (there is no dependentspouse benefit ${ }^{26}$. We did not attempt an imputation procedure to assign spouses to workers because this would generate a significant amount of noise while not adding much to the results. ${ }^{27}$

Disability benefits have not been taken into account because multiple exit routes are not relevant in the Italian case. Also, we do not account for the lump-sum benefit occurring at any separation between employer and employee (the so-called TFR) because, as shown in Brugiavini (1999), this lump-sum benefit does not alter dynamic incentives and would not essentially be affected by the reforms.

To complete the simulation we need information on mortality rates and labor force participation in the population. A full set of mortality rates for each sex-age-cohort combination has been constructed by fitting a grouped-logit model with cohort fixed effects to the sex-age-cohort mortality rates kindly provided by professor Graziella Caselli, of the University of Rome "La Sapienza," and spanning the period 1974 to 1994. On the basis of the mortality rates obtained in this way, and the projected probabilities of exit from the labor force projected for each regime, we infer retirement probabilities at each age between 50 and 70 . We then apply to our results an inflation factor that takes into account the fact that we initially normalize the size of the cohort to 100 workers aged 50 in 1990. The inflation factor has been computed using data from the Italian Labor Force Survey, distinguishing workers by age and sex..$^{28}$

Finally, total fiscal effects are evaluated, both as a percentage of gross benefits under the baseline regime (obtained directly from the simulation exercise) and as a percentage of the gross domestic product (GDP) of the private sector. In the second case, since our sample is confined to private sector employees, we first gross up the results obtained (total gain/loss

26. There is a difference in the rebates on income tax and in the calculation of minimum benefit, particularly in the way means testing is carried out.

27. We have assigned to men a wife who is three years younger, so that in case of death she is entitled to survivors' benefits. Doing so, and further assuming that women are single, leads to three sources of errors: (a) we overestimate benefits to survivors when workers are men, as in reality some are single; (b) we underestimate household social security wealth, by assuming that wives never work, and (c) we underestimate benefits to survivors of working women. We estimated from the SHIW survey that the probability of being married for a man of age 50 is 88 percent. Of these, only 35 percent have a working wife; hence we hope that the combination of overestimation and underestimation may cancel each other out. In any case, it should be noted that none of the reforms changes the basic features of survivors' benefits.

28. This step is necessary in order to produce the total gain/loss. More precisely, in 1990 our sample contains 699 workers born in 1938 to 1940, an average of 233 workers per annual cohort. According to the Labor Force Survey, the population of these cohorts is about 193,000 workers, of which 75 percent are men. Thus, one worker in our sample represents 193,000/233 $=828$ workers in the population. We then multiply our results by the inflation factor in order to produce the effects for the whole population. 
from the reform) for a single representative individual of the cohort, by multiplying by the number of employees (men and women) in the private sector belonging to that cohort. ${ }^{29}$ The result of this calculation is the aggregate effect of the reform, which is then divided by the level of GDP observed in the year 2001 in the private sector (approximately 994 billion euros). It should be noted that GDP in the private sector represents more than 80 percent of Italian GDP.

\subsubsection{Computing Expected Benefits and Fiscal Effects}

Fiscal effects of the reforms are evaluated by computing the net present value of pension expenditures for the cohort of people who are aged $a$ in year $t$ (in our case, age 50 in 1990). We study an initial sample of workers (whose number, $N$, is normalized to be 100) who can leave the labor force through retirement or death. The whole exercise hinges on the definition of expected total gross benefit payments:

$$
T G S W_{i}=\sum_{s=a}^{S}\left[p_{s i}^{R}(X) S S W_{s i}+p_{s i}^{D}(X) S S W_{s i}^{D}\right]
$$

for $i=1, \ldots N$, where $p_{s i}^{R}$ and $p_{s i}^{D}$ are, respectively, the conditional probability of retirement and death at age $a$ for individual $i$. In a general model, both these probabilities would depend on observable characteristics $X$, but in our model the retirement probability is individual specific (projected), while the probability of death is imputed from external data and depends only on sex and age. The terms $S S W$ and $S S W^{D}$ represent the discounted sum of future benefits that would accrue to a worker if he or she was alive and retired at each future age $a$, or to her or his survivor in case of death. ${ }^{30}$ Both are discounted at a 3 percent real discount rate.

A full evaluation of the fiscal effects of the reforms requires a more general approach to the social security budget than can be achieved by looking at the Social Security Administration in isolation. Therefore, a more general approach is required, both from the point of view of the workers belonging to the cohort of interest and from the point of view of fiscal authorities. As for the former, any change to the social security rules would imply a change in retirement/labor supply decisions, which in turn may affect income tax revenue. The latter is easily explained by bearing in mind that the Italian pension system is financed on a pay-as-you-go (PAYG) basis, and is systematically running a deficit. Also, different sources of

29. As we said, we deal with the three year-of-birth cohorts as if the workers all belonged to the same cohort. The number of employees in the private sector of the 1940 cohort (in fact, an average of the 1938, 1939, and 1940 cohorts) is 193,000.

30. It should be noted that while in the econometric exercise we make use of net social security wealth (net of income taxes), in the simulation we proceed in two steps; first, we compute gross social security wealth, and then take off all taxes when aggregating for all individuals. 
revenue should be taken into account, because pension outlays are financed partly through current contributions and partly through taxation at large. Therefore, we cannot identify a specific item of the government revenue to be earmarked to finance the social security budget deficit. For this reason, we compute the present value of future taxes that each worker would pay conditional on work, retirement, or death. ${ }^{31}$ Looking from the perspective of a worker of age 50: for any future year that she works, she pays social security contributions plus income taxes plus VAT; if she retires, she pays income tax on gross benefits and VAT; if she dies, her spouse will pay income tax and VAT on survivors' benefits. Therefore, for any additional year of work, the value of contributions typically grows (due also to a progressive income tax schedule), while the value of gross benefits may increase or decrease depending on eligibility and the rules of the system.

After computing the present value of gross benefits and total taxes for each individual, we select the proper weights (which are based on labor force data and depend on individuals' age and sex) and obtain total projected benefits and taxes for that cohort. Hence we can easily compute total net expected benefits.

These calculations are carried out for each regime. The final step is to compute gains and losses by taking the difference of total net benefits between each different regime $(R 1, R 2, R 3$, and $R 4)$ and the baseline $(R 0)$. The simple difference between the two net quantities provides the total effects of the reform:

$$
\text { Total effect }=\sum_{i=1}^{N} \sum_{s=a}^{S} P_{i s}^{R 1} N T S W_{i s}^{R 1}-\sum_{i=1}^{N} \sum_{s=a}^{S} P_{i s}^{R 0} N T S W_{i s}^{R 0},
$$

where $R 1$ stands for the first regime (or any of the reforms), $R 0$ stands for the baseline regime, and NTSW indicates the present value of total net benefits. We can also compute the mechanical effect and the behavioral effect of the reforms as follows:

$$
\begin{aligned}
\text { Mechanical effect } & =\sum_{i=1}^{N} \sum_{s=a}^{S} P_{i s}^{R 0} N T S W_{i s}^{R 1}-\sum_{i=1}^{N} \sum_{s=a}^{S} P_{i s}^{R 0} N T S W_{i s}^{R 0} \\
\text { Behavioral effect } & =\sum_{i=1}^{N} \sum_{s=a}^{S} P_{i s}^{R 1} N T S W_{i s}^{R 1}-\sum_{i=1}^{N} \sum_{s=a}^{S} P_{i s}^{R 0} N T S W_{i s}^{R 1}
\end{aligned}
$$

The mechanical effect freezes the retirement probabilities at the prereform values, so that the only changes are due to changes of the social security rules. The behavioral effect maintains the same value for the net expected benefits (values after the reform), but changes the probabilities according to the regime under evaluation.

31. A detailed description of the assumptions regarding the tax base and tax rates is given in the appendix. 


\subsection{Results}

Results are better described by looking separately at each regime change, so that we can discuss the simulation strategy implemented in each specific case. An overall summary of the results is provided in table 6.3 and table 6.4. The former shows the total fiscal impact of the three reforms, $R 1$, $R 2$, and $R 3$, whereas the latter decomposes these total effects into mechanical and behavioral effects. It should be noted that, although the results are presented as total effects for workers born between 1938 and 1940, the unit of analysis is really the household. To be more precise, given our assumptions on marital status, we essentially describe a stylized economy of married male workers (in which case we have household social security wealth) and single female workers. For brevity, in this section we only comment on results obtained using the option value as the incentive variable. The full set of results can be found in tables 6.3 and 6.4, and in the corresponding figures (figure 6.3 through 6.28). The total effects given in these tables have been obtained by aggregating the individual with weights given by the inflation factors described previously in section 6.4. Because, as we shall argue, the econometric specification based on the linear term does not provide a good representation of the behavior of Italian workers, we focus our attention on the model based on age dummies. ${ }^{32}$

\section{R1: Three-Year Reform}

This reform entails a shift of the hazard by three years, while all other features of the social security system are preserved as under the baseline. The reform has a direct effect on the hazard and an indirect effect on benefits through eligibility. It should be noted that when using the linear age model, the projected age profile of labor force exits does not accurately capture the empirical hazard (figures 6.1 and 6.2): exits are evenly distributed over ages, and there is a hump around age 55 (figure 6.3). Instead, the empirical hazard shows higher variability and marked spikes at ages 55 and 60 (figure 6.1). Furthermore, the age distribution by age of retirement rates is essentially unaffected by the reform (figure 6.3). This is because the linear term does not pick up any of the policy changes, and as a result the behavioral effect is negligible.

For the model with a linear age term, the present value of benefits is reduced by 11.40 percent relative to the baseline value. Because taxes are also reduced by the reform, the total net change is -9.5 percent (table 6.3). Most of the impact of the reform is due to the mechanical effect ( -9.6 percent).

32. Also, it should be noted that after age 66 there are very few workers left in the dataset, so that the estimated hazard is very volatile. We decided to set the hazard of exits (for retirement or death) equal to 0.5 after age 66 and equal to 1 at the latest age (69). The value 0.5 emerges as the estimated value at age 65 , which is the last age that we have a reasonable sample size available. 
Total fiscal impact of reforms

\begin{tabular}{|c|c|c|c|c|c|c|c|}
\hline & \multicolumn{4}{|c|}{ Present discounted value } & \multicolumn{3}{|c|}{ Total change relative to base $(\%)$} \\
\hline & Base & $\begin{array}{c}\text { Three-Year } \\
\text { Reform }\end{array}$ & $\begin{array}{c}\text { Actuarial } \\
\text { Reform }\end{array}$ & $\begin{array}{c}\text { Common } \\
\text { Reform }\end{array}$ & $\begin{array}{c}\text { Three-Year } \\
\text { Reform }\end{array}$ & $\begin{array}{c}\text { Actuarial } \\
\text { Reform }\end{array}$ & $\begin{array}{c}\text { Common } \\
\text { Reform }\end{array}$ \\
\hline \multicolumn{8}{|c|}{ Peak value-Linear age } \\
\hline Benefits & 168,752 & 148,332 & 141,059 & 62,376 & -12.10 & -16.41 & -63.04 \\
\hline \multicolumn{8}{|l|}{ Taxes } \\
\hline Payroll & 31,869 & 31,481 & 32,562 & 33,379 & -1.22 & 2.17 & 4.74 \\
\hline Income & 25,301 & 23,464 & 20,812 & 12,806 & -7.26 & -17.74 & -49.39 \\
\hline VAT & 16,873 & 15,425 & 15,299 & 10,128 & -8.58 & -9.33 & -39.98 \\
\hline Total & 74,042 & 70,370 & 68,673 & 56,313 & -4.96 & -7.25 & -23.94 \\
\hline \multicolumn{8}{|c|}{ Peak value-Age dummies } \\
\hline Benefits & 168,016 & 141,632 & 142,282 & 63,683 & -15.70 & -15.32 & -62.10 \\
\hline \multicolumn{8}{|l|}{ Taxes } \\
\hline Payroll & 32,398 & 37,133 & 33,375 & 33,549 & 14.62 & 3.02 & 3.55 \\
\hline Income & 25,847 & 25,771 & 22,083 & 13,686 & -0.29 & -14.56 & -47.05 \\
\hline VAT & 16,879 & 15,731 & 15,448 & 10,186 & -6.80 & -8.48 & -39.65 \\
\hline Total & 75,124 & 78,635 & 70,906 & 57,422 & 4.67 & -5.61 & -23.56 \\
\hline \multicolumn{8}{|c|}{ Option value - Linear age } \\
\hline Benefits & 168,002 & 148,856 & 142,463 & 61,972 & -11.40 & -15.20 & -63.11 \\
\hline \multicolumn{8}{|l|}{ Taxes } \\
\hline Payroll & 32,730 & 32,555 & 32,874 & 32,876 & -0.53 & 0.44 & 0.45 \\
\hline Income & 25,607 & 23,955 & 21,044 & 12,415 & -6.45 & -17.82 & -51.52 \\
\hline VAT & 16,959 & 15,633 & 15,457 & 10,031 & -7.82 & -8.86 & -40.85 \\
\hline Total & 75,296 & 72,143 & 69,375 & 55,322 & -4.19 & -7.86 & -26.53 \\
\hline \multicolumn{8}{|c|}{ Option value - Age dummies } \\
\hline Benefits & 166,778 & 142,067 & 145,207 & 65,357 & -14.82 & -12.93 & -60.81 \\
\hline \multicolumn{8}{|l|}{ Taxes } \\
\hline Payroll & 33,387 & 38,048 & 35,399 & 35,079 & 13.96 & 6.03 & 5.07 \\
\hline Income & 26,214 & 26,271 & 24,031 & 14,747 & 0.22 & -8.33 & -43.74 \\
\hline VAT & 16,949 & 15,905 & 15,907 & 10,515 & -6.16 & -6.15 & -37.96 \\
\hline Total & 76,549 & 80,223 & 75,337 & 60,341 & 4.80 & -1.58 & -21.17 \\
\hline
\end{tabular}

Note: Values in 2001 euros.

The behavioral effect, albeit very small, runs opposite to what one would expect ( 0.1 percent), because retirement probabilities are higher at younger ages after the reform, and precisely at those ages losses would be greater (table 6.4 and figure 6.4). As for distributional effects, table 6.5 shows that losses are evenly spread over the population: people next to the highest quintile (quintile 4) suffer most from the reform, but the loss in terms of net present value of benefits is not much higher than for the population at large.

For the model with age dummies, which is documented in figures 6.5 through 6.9, retirement probabilities are much closer to the empirical hazard; this is clearly shown by the age distribution of labor force exits (figure 


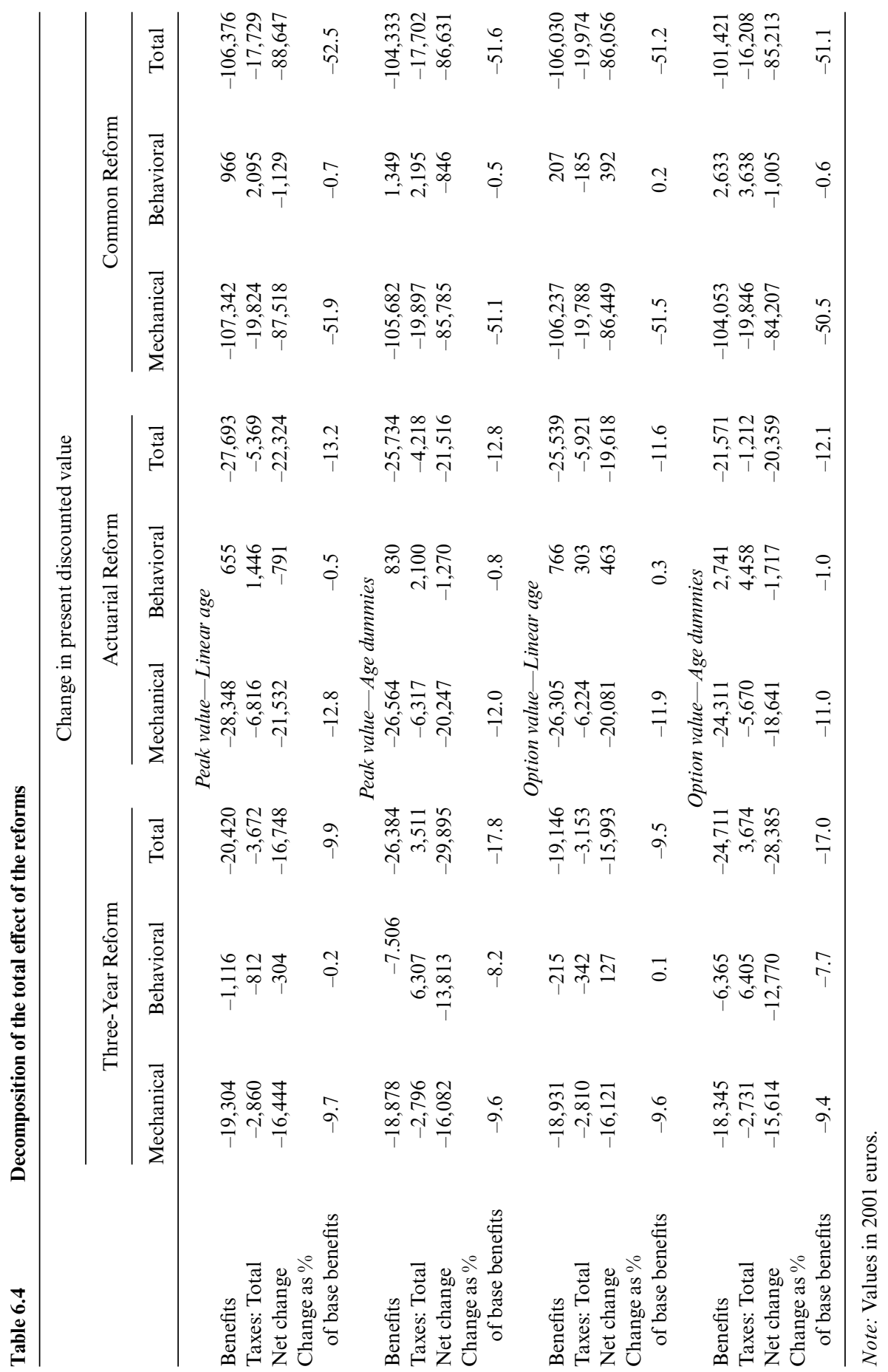




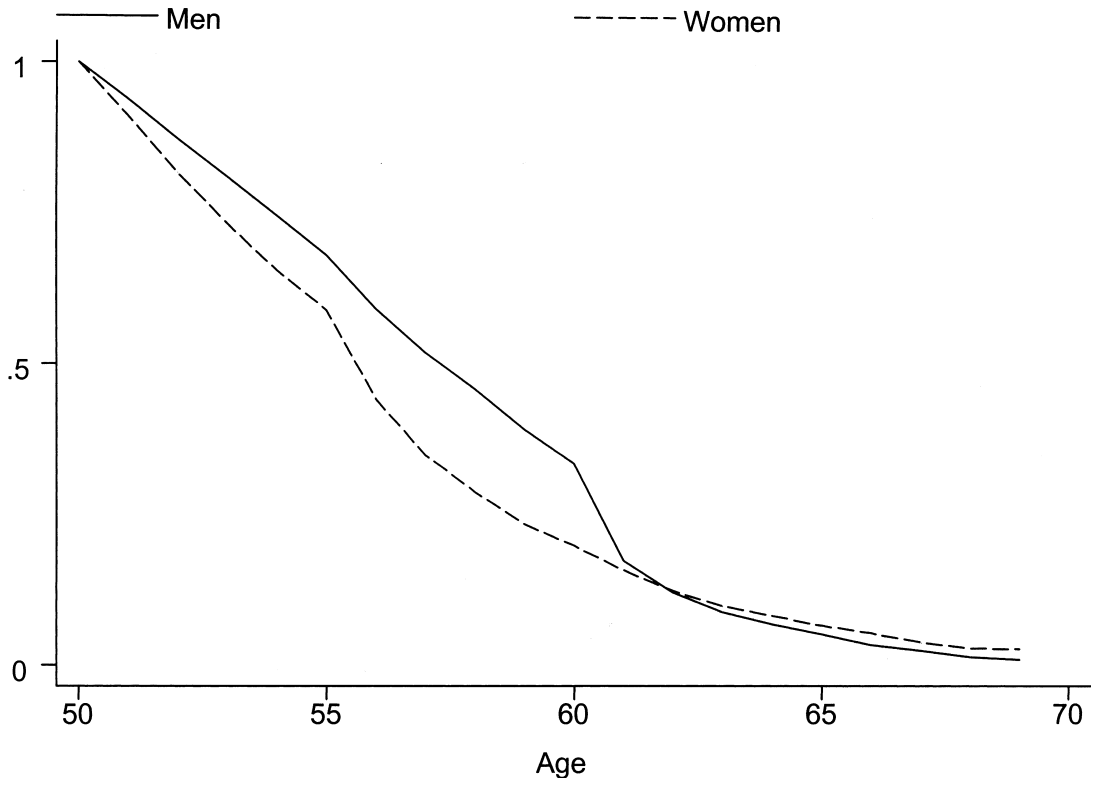

Fig. 6.2 Empirical survival curve in the INPS sample

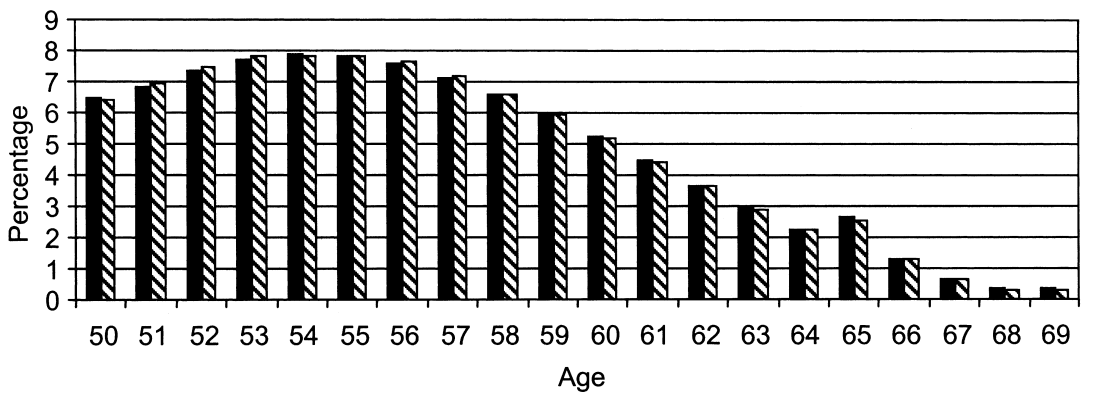

- Base Case $\quad$ Age Shift Reform

Fig. 6.3 Three-Year Reform-Option value, distribution of age of labor force exit (OV linear age)

Note: Figures in percentage terms. 


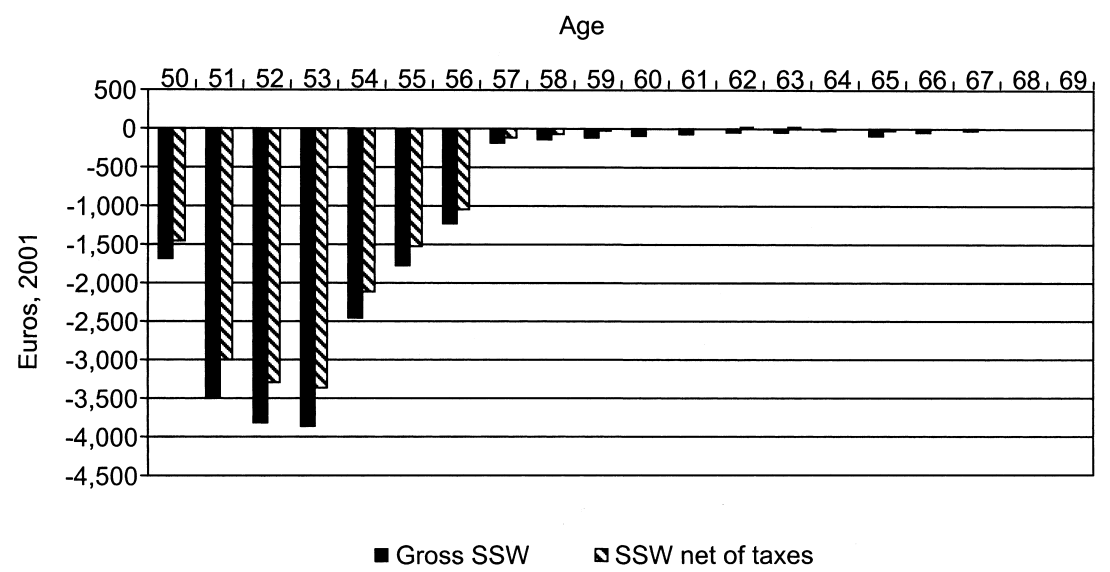

Fig. 6.4 Three-Year Reform-Option value, total effect by age of retirement (OV linear age)

Note: Values in euros of 2001.

6.5)..$^{33}$ The reform clearly affects retirement behavior: the distribution of retirement rates is shifted toward older ages, and the spikes are observed to occur with three years' delay. This implies that while a substantial fraction of losses are suffered at ages 50 to 57 , they tend to be very high at ages 55 and 60 (the normal retirement age of women and men under the baseline). Older retirees would instead gain from the reform, because of the increase in benefits at older ages.

When the econometric model allows for age dummies, we not only observe a decline in benefits (-14.82 percent relative to the baseline), but also an increase in the overall fiscal impact (4.80 percent), so that the total net effect is -17.0 percent (table 6.3 and figures 6.8 and 6.9). This is largely due to the mechanical effect, although, as shown in table 6.4 and figure 6.7 , a nonnegligible role is played by the behavioral effect ( -7.7 percent). Note that figure 6.7 reports the results as a percentage of private-sector GDP: these are small (the total effect is approximately -0.5 percent), but one should bear in mind that social security spending is approximately 14 percent of total GDP in Italy. In this sense, the implied saving for the budget may be nonnegligible. The distributional effects of the reform are significant, with the highest quintile of social security wealth suffering a loss of approximately 20 percent against a 12.4 percent loss at the lowest quintile (table 6.6). Hence, according to this model, a reform that shifts the retirement age by three years in Italy would be effective in reducing outlays and would also be progressive.

33. Besides changing the eligibility rules, we increment all age dummies by three years, so that the normal retirement age is effectively increased by three years. 
Distribution analysis: Option value - Model with linear age

\begin{tabular}{|c|c|c|c|c|c|c|c|}
\hline & \multirow{2}{*}{\multicolumn{4}{|c|}{ Present discounted value }} & \multicolumn{3}{|c|}{ Change relative to base PDV } \\
\hline & & & & & \multirow{2}{*}{$\begin{array}{l}\text { Three-Year } \\
\text { Reform }\end{array}$} & \multirow{2}{*}{$\begin{array}{l}\text { Actuarial } \\
\text { Reform }\end{array}$} & \multirow{2}{*}{$\begin{array}{c}\text { Common } \\
\text { Reform }\end{array}$} \\
\hline & Base & Three-Year & Actuarial & Common & & & \\
\hline \multicolumn{8}{|c|}{ Quintile 5 (highest) } \\
\hline Benefits & 13,163 & 11,516 & 10,583 & 4,628 & $-1,647$ & $-2,580$ & $-8,535$ \\
\hline After-tax income & 11,883 & 10,486 & 10,096 & 5,162 & $-1,396$ & $-1,787$ & $-6,721$ \\
\hline \multicolumn{8}{|c|}{ Taxes } \\
\hline Payroll & 3,478 & 3,448 & 3,415 & 3,386 & -30 & -64 & -92 \\
\hline Income & 4,194 & 3,929 & 3,356 & 2,301 & -264 & -837 & $-1,893$ \\
\hline VAT & 1,338 & 1,230 & 1,200 & 825 & -108 & -139 & -514 \\
\hline Total & 9,010 & 8,607 & 7,971 & 6,512 & -403 & $-1,040$ & $-2,499$ \\
\hline Net change & & & & & $-1,244$ & $-1,540$ & $-6,036$ \\
\hline $\begin{array}{c}\text { Change as } \% \text { of } \\
\text { base benefits }\end{array}$ & \multicolumn{6}{|c|}{ Change as $\%$ of } & -45.86 \\
\hline \multicolumn{8}{|c|}{ Quintile 4} \\
\hline Benefits & 10,603 & 9,281 & 8,336 & 3,081 & $-1,322$ & $-2,268$ & $-7,522$ \\
\hline Taxes: Total & 4,378 & 4,161 & 3,893 & 3,009 & -217 & -485 & $-1,369$ \\
\hline Net change & & & & & $-1,105$ & $-1,783$ & $-6,153$ \\
\hline Change as $\%$ of & & & & & & & \\
\hline base benefits & & & & & -10.43 & -16.81 & -58.03 \\
\hline \multicolumn{8}{|c|}{ Quintile 3} \\
\hline Benefits & 8,466 & 7,543 & 7,240 & 2,786 & -923 & $-1,226$ & $-5,680$ \\
\hline Taxes: Total & 2,788 & 2,693 & 2,737 & 2,119 & -95 & -51 & -670 \\
\hline Net change & & & & & -828 & $-1,175$ & $-5,011$ \\
\hline $\begin{array}{c}\text { Change as } \% \text { of } \\
\text { base benefits }\end{array}$ & & & & & -9.78 & -13.88 & -59.19 \\
\hline \multicolumn{8}{|c|}{ Quintile 2} \\
\hline Benefits & 6,006 & 5,435 & 5,613 & 2,550 & -572 & -393 & $-3,457$ \\
\hline Taxes: Total & 1,779 & 1,734 & 1,855 & 1,454 & -45 & 75 & -325 \\
\hline Net change & & & & & -526 & -469 & $-3,132$ \\
\hline \multicolumn{8}{|l|}{ Change as $\%$ of } \\
\hline base benefits & & & & & -8.76 & -7.80 & -52.14 \\
\hline \multicolumn{8}{|c|}{ Quintile 1 (lowest) } \\
\hline Benefits & 3,763 & 3,441 & 3,849 & 2,455 & -322 & 86 & $-1,308$ \\
\hline Taxes: Total & 887 & 859 & 906 & 752 & -28 & 19 & -135 \\
\hline Net change & & & & & -293 & 68 & $-1,173$ \\
\hline \multicolumn{8}{|l|}{ Change as $\%$ of } \\
\hline base benefits & & & & & -7.80 & 1.80 & -31.17 \\
\hline
\end{tabular}

Note: Values in 2001 euros.

\section{R2: Actuarial Reform}

The basic idea of this reform is to preserve the status quo in several respects as well as to introduce an actuarial adjustment in order to guarantee neutrality of the system with respect to the retirement age. Before describing the results in detail, it is useful to remind the reader that the 


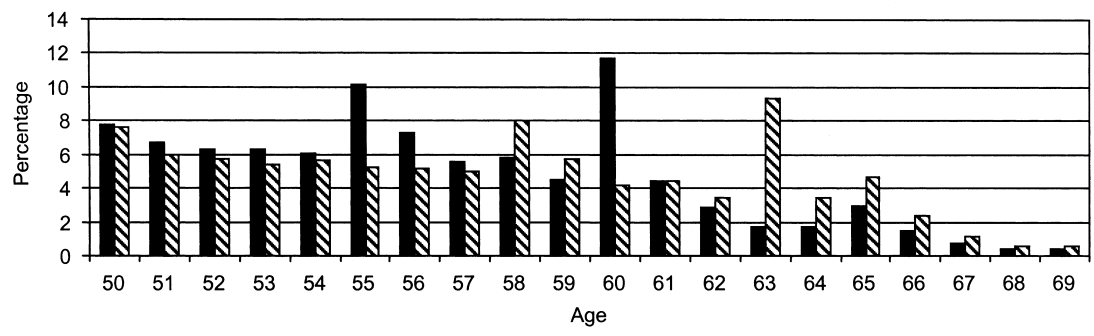

- Base Case $\quad \square$ Age Shift Reform

Fig. 6.5 Three-Year Reform-Option value, distribution of age and labor force exit (OV age dummies)

Note: Figures in percentage terms.

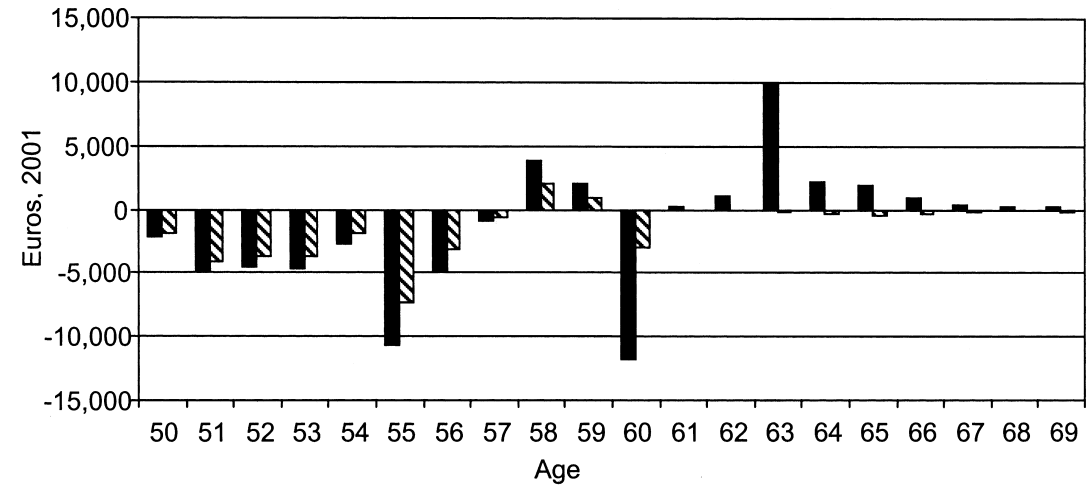

- Gross SSW $\quad$ SSW net of taxes

Fig. 6.6 Three-Year Reform-Option value, total effect by age of retirement (OV age dummies)

Note: Values in euros of 2001.

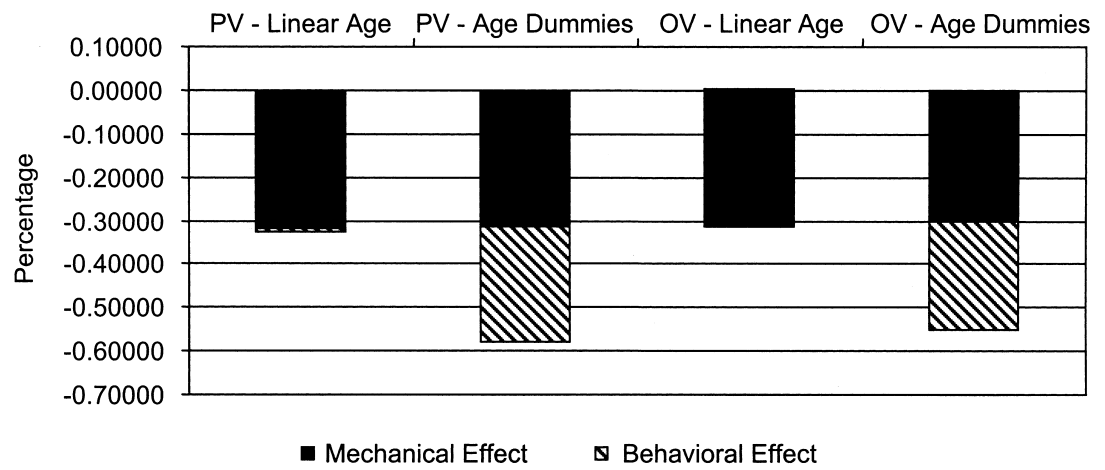

Fig. 6.7 Three-Year Reform-Option value, fiscal implications of Three-Year Reform as a percentage of GDP 


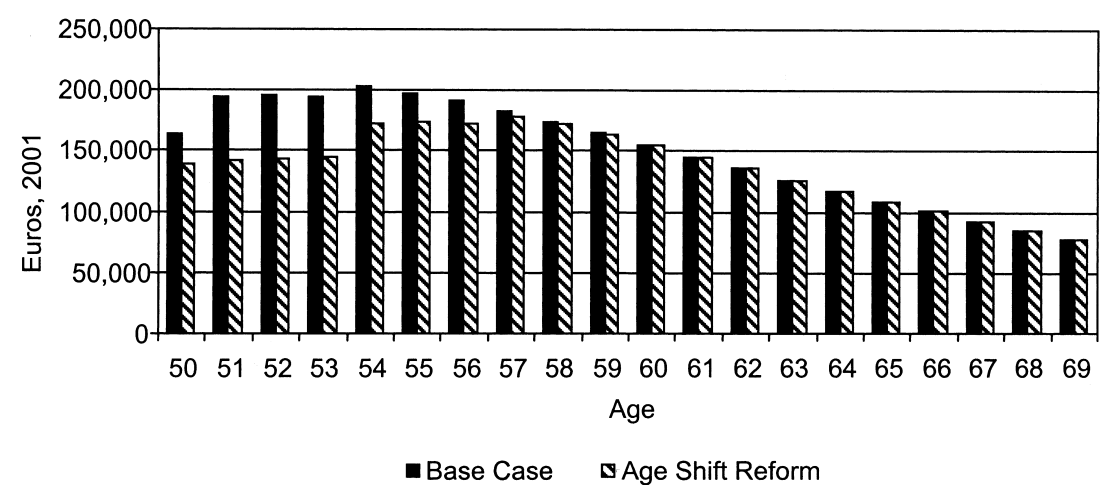

Fig. 6.8 Three-Year Reform-Option value, SSW by age of labor force exit (OV age dummies)

Note: Values in euros of 2001.

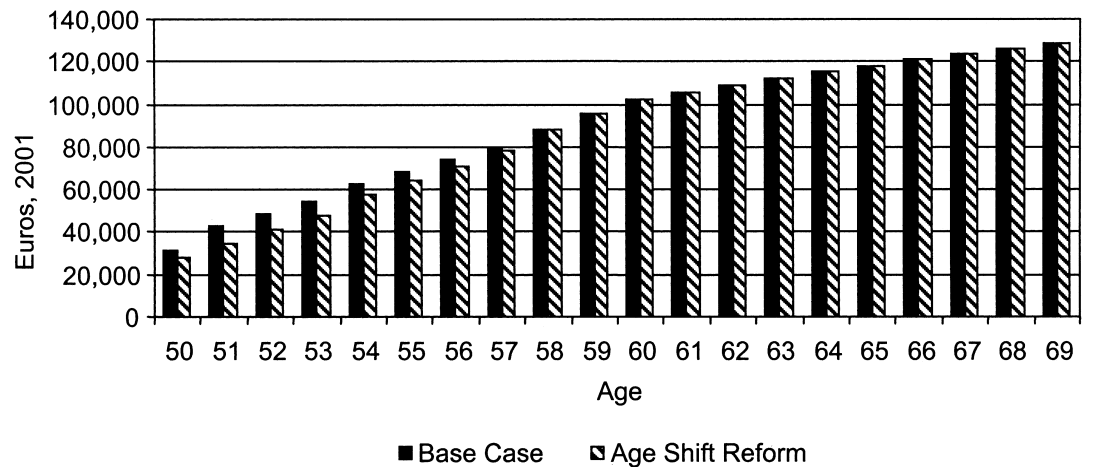

Fig. 6.9 Three-Year Reform-Option value, taxes by age of labor force exit (OV age dummies)

Note: Values in euros of 2001.

baseline (pre-1993) is very far from being actuarially fair, as no actuarial penalties are envisaged for early retirement (and no bonus for late retirement).

As we already argued, the linear case is not very interesting for the Italian system. This can be easily understood by looking at figures 6.10 and 6.11 , where a very smooth age profile of exit probabilities is shown, which is quite different from the observed hazard.

Focusing one's attention on figure 6.12, one can see that the Actuarial Reform has some effect on the age distribution of retirement probabilities. In fact, although their basic pattern is unchanged after the reform, exits from the labor force are lower at younger ages and higher at older ages. 
Distribution analysis: Option value - model with age dummies

\begin{tabular}{|c|c|c|c|c|c|c|c|}
\hline & \multirow{2}{*}{\multicolumn{4}{|c|}{ Present discounted value }} & \multicolumn{3}{|c|}{ Change relative to base PDV } \\
\hline & & & & & \multirow{2}{*}{$\begin{array}{l}\text { Three-Year } \\
\text { Reform }\end{array}$} & \multirow{2}{*}{$\begin{array}{l}\text { Actuarial } \\
\text { Reform }\end{array}$} & \multirow{2}{*}{$\begin{array}{c}\text { Common } \\
\text { Reform }\end{array}$} \\
\hline & Base & Three-Year & Actuarial & Common & & & \\
\hline \multicolumn{8}{|c|}{ Quintile 5 (highest) } \\
\hline Benefits & 13,185 & 11,078 & 11,100 & 5,344 & $-2,107$ & $-2,085$ & $-7,841$ \\
\hline After-tax income & 11,839 & 9,936 & 10,255 & 5,585 & $-1,904$ & $-1,584$ & $-6,255$ \\
\hline \multicolumn{8}{|c|}{ Taxes } \\
\hline Payroll & 3,550 & 4,103 & 3,879 & 3,980 & 553 & 329 & 430 \\
\hline Income & 4,283 & 4,304 & 3,927 & 2,884 & 21 & -356 & $-1,399$ \\
\hline VAT & 1,348 & 1,283 & 1,281 & 942 & -65 & -67 & -406 \\
\hline Total & 9,181 & 9,690 & 9,087 & 7,805 & 509 & -94 & $-1,376$ \\
\hline Net change & & & & & $-2,616$ & $-1,991$ & $-6,465$ \\
\hline \multicolumn{8}{|l|}{ Change as $\%$ of } \\
\hline base benefits & & & & & -19.84 & -15.10 & -49.04 \\
\hline \multicolumn{8}{|c|}{ Quintile 4} \\
\hline Benefits & 10,429 & 8,753 & 8,449 & 3,161 & $-1,677$ & $-1,980$ & $-7,269$ \\
\hline Taxes: Total & 4,474 & 4,638 & 4,166 & 3,118 & 164 & -308 & $-1,356$ \\
\hline Net change & & & & & $-1,841$ & $-1,672$ & $-5,912$ \\
\hline \multicolumn{8}{|l|}{ Change as $\%$ of } \\
\hline base benefits & & & & & -17.65 & -16.03 & -56.69 \\
\hline \multicolumn{8}{|c|}{ Quintile 3} \\
\hline Benefits & 8,344 & 7,159 & 7,271 & 2,777 & $-1,185$ & $-1,073$ & $-5,567$ \\
\hline Taxes: Total & 2,840 & 2,981 & 2,855 & 2,084 & 141 & 15 & -757 \\
\hline Net change & & & & & $-1,326$ & $-1,088$ & $-4,810$ \\
\hline \multicolumn{8}{|l|}{ Change as $\%$ of } \\
\hline base benefits & & & & & -15.90 & -13.03 & -57.65 \\
\hline \multicolumn{8}{|c|}{ Quintile 2} \\
\hline Benefits & 5,970 & 5,212 & 5,613 & 2,559 & -758 & -356 & $-3,410$ \\
\hline Taxes: Total & 1,785 & 1,873 & 1,865 & 1,387 & 88 & 80 & -397 \\
\hline Net change & & & & & -846 & -436 & $-3,013$ \\
\hline \multicolumn{8}{|l|}{ Change as $\%$ of } \\
\hline base benefits & & & & & -14.18 & -7.31 & -50.47 \\
\hline \multicolumn{8}{|c|}{ Quintile 1 (lowest) } \\
\hline Benefits & 3,769 & 3,319 & 3,875 & 2,509 & -450 & 106 & $-1,260$ \\
\hline Taxes: Total & 876 & 894 & 883 & 713 & 18 & 6 & -163 \\
\hline Net change & & & & & -468 & 99 & $-1,097$ \\
\hline \multicolumn{8}{|l|}{ Change as $\%$ of } \\
\hline base benefits & & & & & -12.41 & 2.64 & -29.11 \\
\hline
\end{tabular}

Note: Values in 2001 euros.

Coupled with the actual reduction of benefits that the reform envisages for younger retirees (figure 6.13), this implies that gross benefits are reduced (12.93 percent). Since total taxes are also marginally reduced $(-1.58$ percent), the net effect is -12.1 percent of baseline gross benefits (table 6.3 and table 6.4). The effect is largely due to the actual reduction in benefits; that 


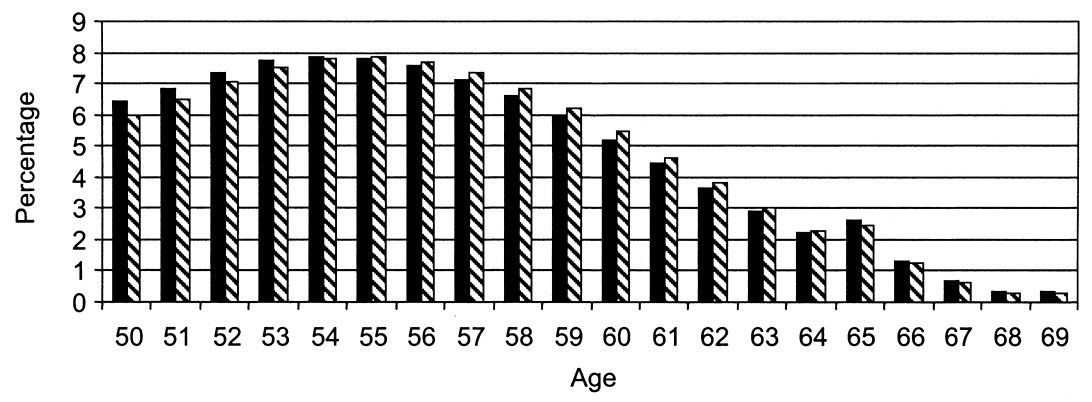

- Base Case $\mathbf{\Delta}$ Actuarial Adjustment Reform

Fig. 6.10 Actuarial Reform-Option value, distribution of age of labor force exit (OV linear age)

Note: Values in percentage terms.

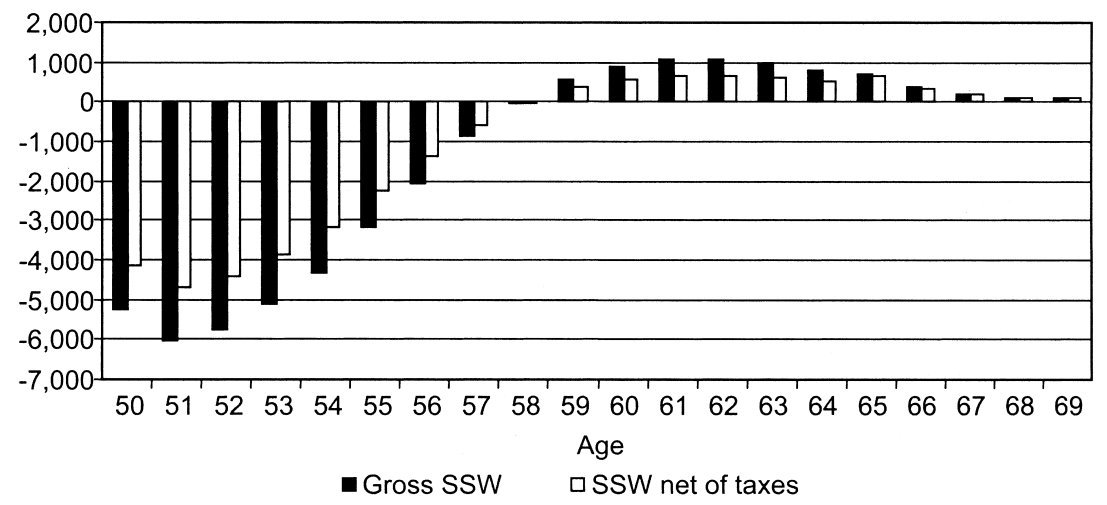

Fig. 6.11 Actuarial Reform-Option value, total effect by age of retirement (OV linear age)

Note: Values in euros of 2001.

is, the mechanical component is prevalent ( -11 percent), although the behavioral effect goes in the expected direction (table 6.4 and figure 6.14). In terms of private sector GDP, the revenue gains are of the order of 0.4 percentage points. The distributional effects are interesting, both in terms of age distribution and of welfare. Losses are concentrated in the age group 50 to 57, while gainers are retirees aged 58 to 69 (figure 6.15). A clear ranking also emerges in terms of wealth distribution: the highest losses are suffered by rich retirees ( -15.1 percent and -16 percent respectively for the 5 th and 4th quintiles of social security wealth), while the poor retirees gain from this reform (table 6.6). 


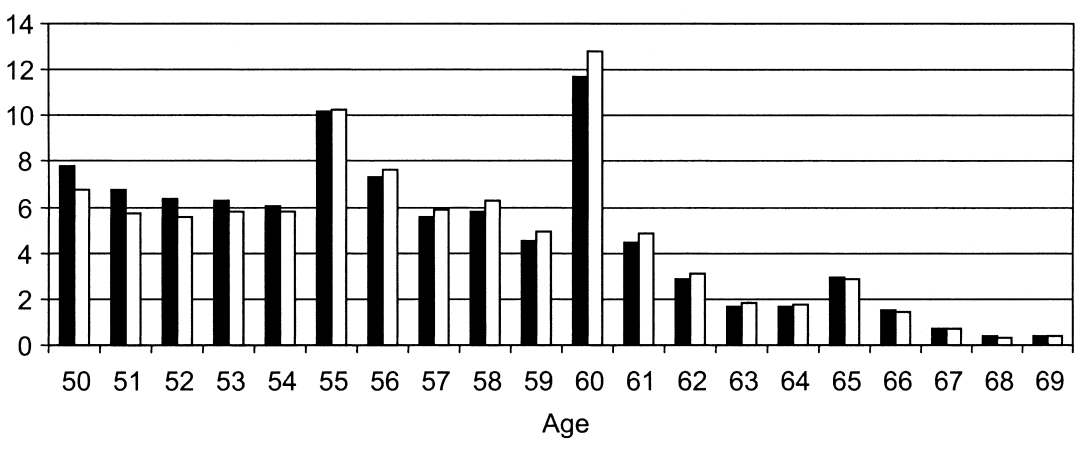

- Base Case $\square$ Actuarial Adjustment Reform

Fig. 6.12 Actuarial Reform-Option value, distribution of age of labor force exit (OV age dummies)

Note: Values in percentage terms.

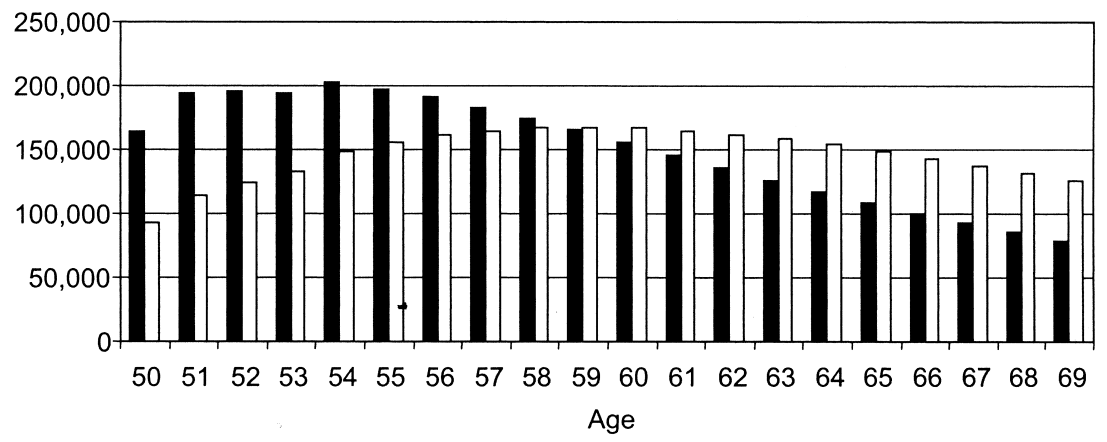

- Base Case $\quad$ Actuarial Adjustment Reform

Fig. 6.13 Actuarial Reform-Option value, SSW by age of labor force exit Note: Values in euros of 2001.

\section{R3: Common Reform}

The Common Reform is a hypothetical reform that introduces very different rules from the ones currently in place in Italy. On average, benefits are lower: the gross replacement rate for a fully eligible Italian worker is 80 percent at age 60 under the baseline, but would become 60 percent at age 65 under the Common Reform. Penalties for early retirement are nonexistent under the baseline, but would be substantial under R3. One further important difference is the indexation rule: in the pre-1993 system, benefits were indexed to nominal wages, while the Common Reform (as well as the post-1993 regime) only indexes benefits to prices. It should be 


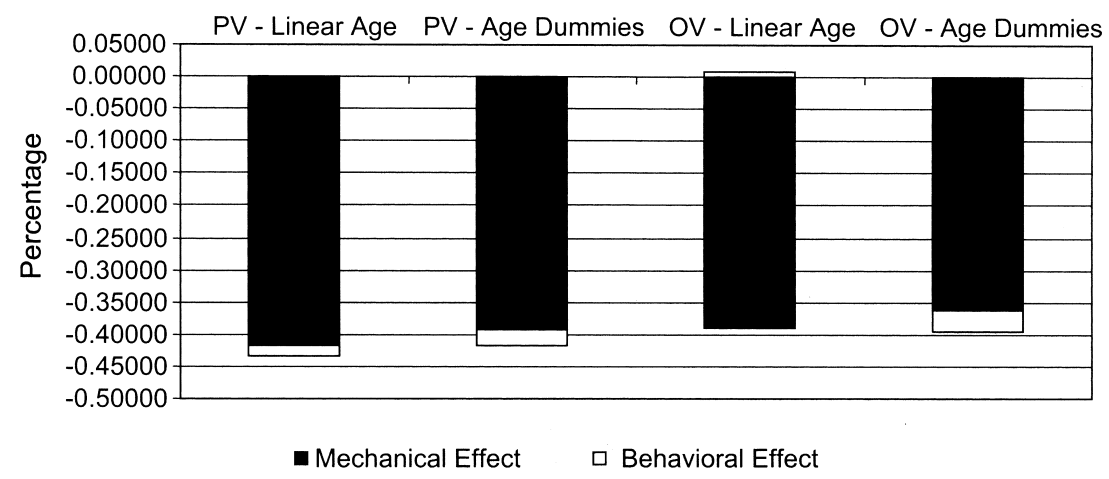

Fig. 6.14 Actuarial Reform-Option value, fiscal implications of Actuarial Reform as a percentage of GDP

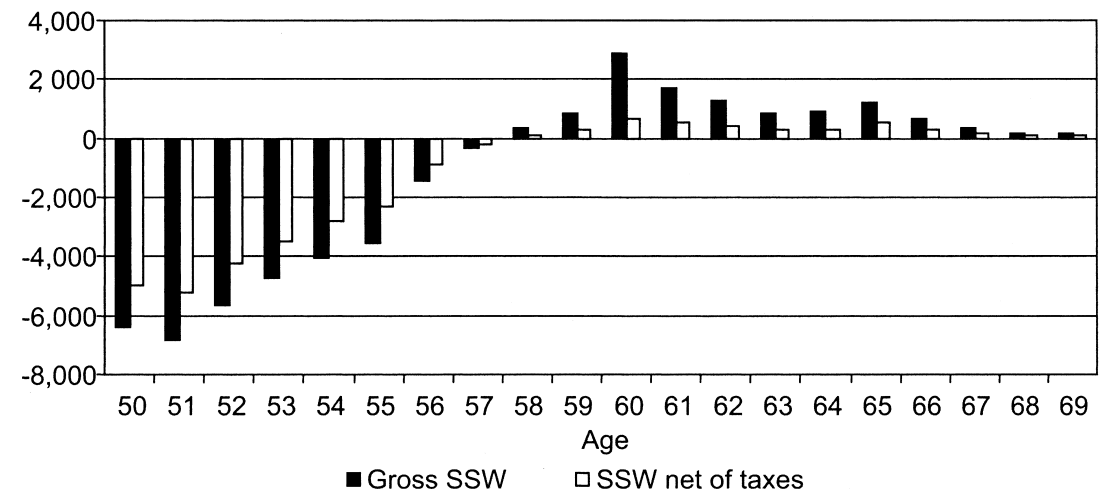

Fig. 6.15 Actuarial Reform-Option value, total effect by age of retirement (OV age dummies)

noted that in order to identify which specific feature of the reform produced the most important changes, we kept the legislation concerning capping and eligibility to minimum benefits unchanged with respect to the baseline (figures 6.16-6.18).

Figure 6.19 shows the distribution of labor force exits by age when use is made of the model with age dummies. ${ }^{34}$ This reform reduces the exit rates at younger ages and shifts their distribution toward older ages. Gross benefits are much lower at all ages, in particular between 50 and 60. Table 6.3

34. The effect of the age dummies estimated in the hazard of exits (to retirement and to death) is slightly modified in this simulation to take account of the fact that we have implicitly moved the normal retirement age forward. Therefore, the age effect observed at age 60 should be felt at age 65 after the reform. The change is done through a smoothing procedure. 


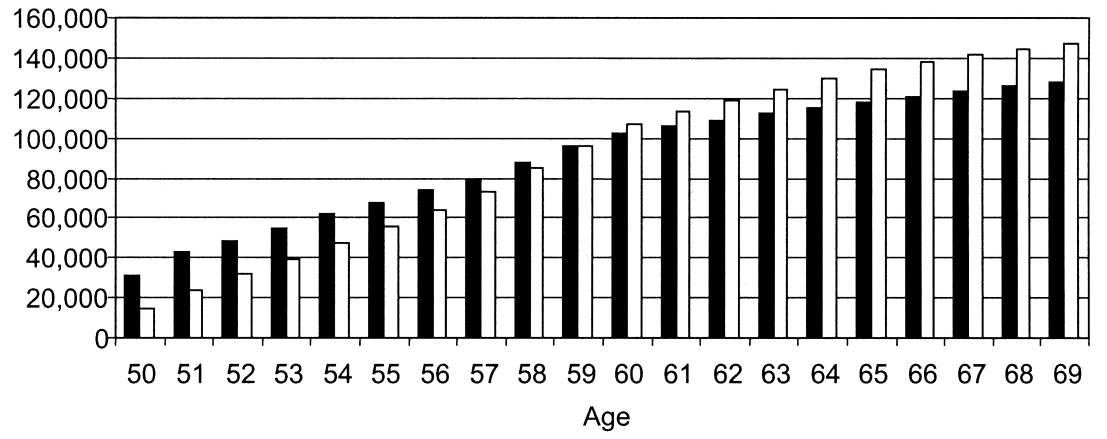

- Base Case $\square$ Actuarial Adjustment Reform

Fig. 6.16 Actuarial Reform-Option value, taxes by age of labor force exit Note: Values in euros of 2001.

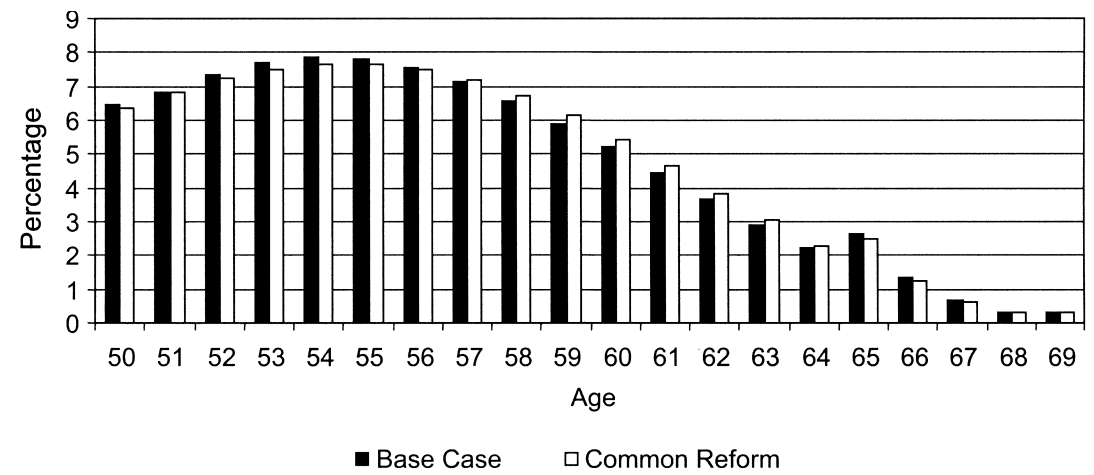

Fig. 6.17 Common Reform-Option value, distribution of age of labor force exit (OV linear age)

Note: Values in percentage terms.

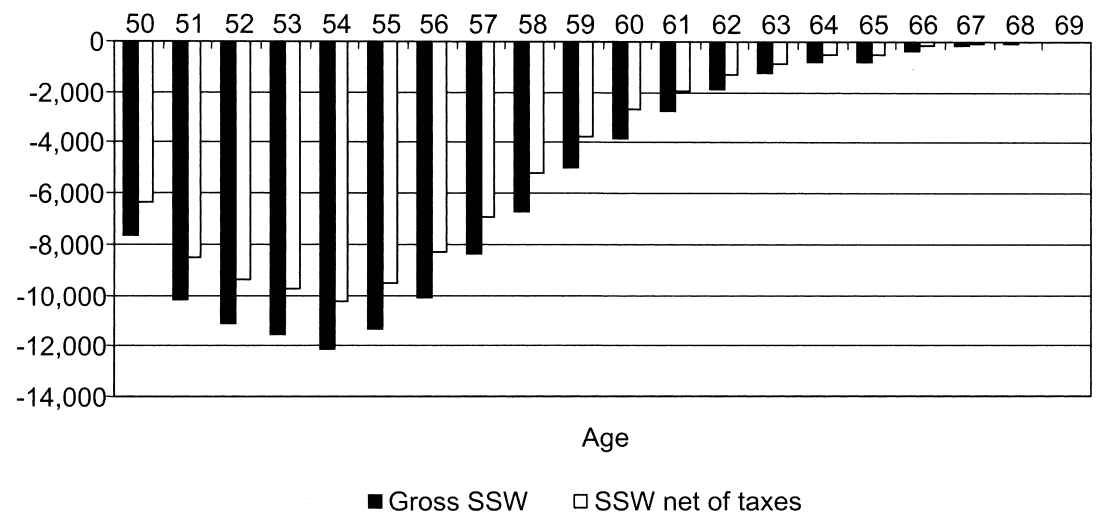

Fig. 6.18 Common Reform-Option value, total effect by age of retirement (OV linear age)

Note: Values in euros of 2001. 


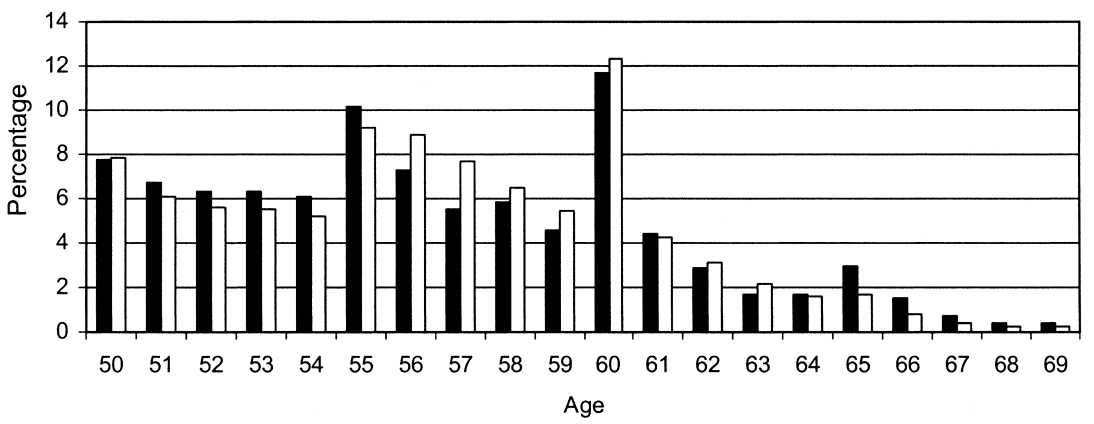

- Base Case $\square$ Common Reform

Fig. 6.19 Common Reform-Option value, distribution of age in labor force exit (OV age dummies)

Note: Values in percentage terms.

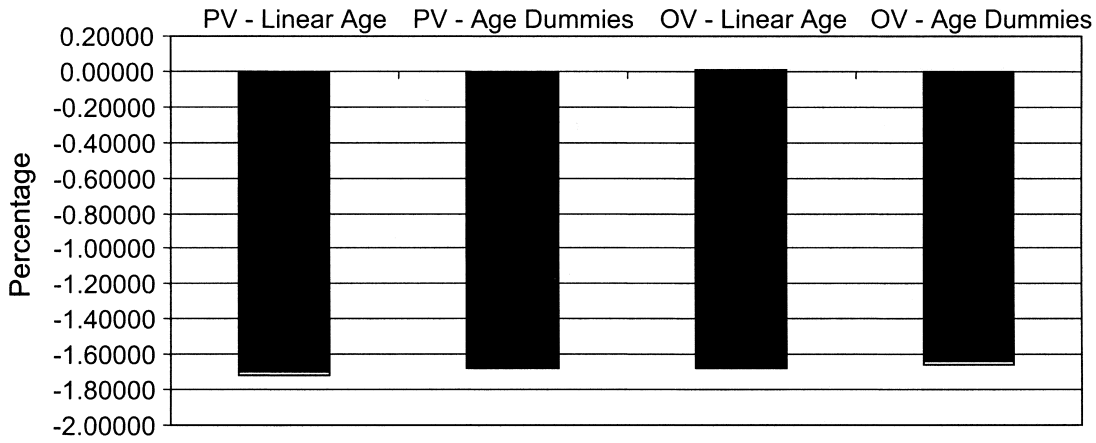

- Mechanical Effect $\quad \square$ Fiscal Implications of the Behavioral Effect

Fig. 6.20 Common Reform-Option value, fiscal implications of Common Reform as a percent of GDP

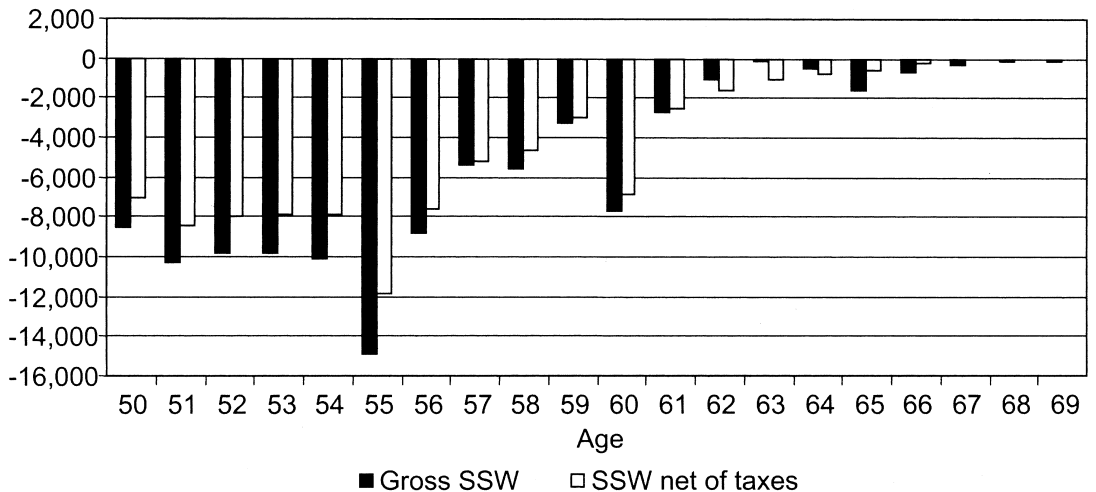

Fig. 6.21 Common Reform-Option value, total effect by age of retirement (OV age dummies)

Note: Values in euros of 2001. 


\begin{tabular}{lccc}
\hline & \multicolumn{3}{c}{ Change in present discounted value } \\
\cline { 2 - 4 } & \multicolumn{3}{c}{ Three-Year Reform } \\
\cline { 2 - 4 } & Mechanical & Behavioral & Total \\
\hline & Peak value - Age dummies & \\
Benefits & $-68,054$ & $-1,890$ & $-69,944$ \\
Taxes: Total & $-13,953$ & 27,045 & 13,093 \\
Net change & $-54,101$ & $-28,935$ & $-83,037$ \\
Change as \% of base benefits & -32.2 & -17.2 & -49.4 \\
& Option value-Age dummies & & \\
Benefits & $-67,114$ & $-2,142$ & $-69,256$ \\
Taxes: Total & $-13,895$ & 26,326 & 12,431 \\
Net change & $-53,219$ & $-28,468$ & $-81,687$ \\
Change as \% of base benefits & -31.9 & -17.1 & -49.0 \\
\hline
\end{tabular}

shows that, for all the reasons given earlier, the total impact on gross benefits is huge ( -60.8 percent). However, taxes are also lower, particularly income tax, so that the total net effect with respect to baseline benefits is 51.1 percent. This is almost completely explained by the mechanical effect that swamps the small gain due to delayed retirement (table 6.4). As shown in figure 6.20, the total effect is quite sizeable in terms of GDP: the fiscal authorities would gain approximately 1.6 percent of private sector GDP.

The largest losses are suffered by workers retiring at ages 55 and 60 , which are the normal retirement ages under the baseline. In general, the bulk of the fiscal saving for the government comes from the age group 50 to 60 (figure 6.21). In terms of wealth distribution everyone loses from the reform, but the median retiree (3rd quintile) appears to lose more, whereas retirees placed at the lowest quintile suffer the smallest loss (table 6.7).

\section{R4: The Dini Reform}

This is the actual reform enacted in 1995 by the Dini government. As described in sections 6.2 and 6.3 , at the steady state this reform would represent a radical departure from the baseline in all respects. By introducing a notionally defined contribution method of calculation of benefits, it implies a potential reduction in the present value of benefits for many workers. It also introduces actuarial principles in the benefit computation formula, as well as indexation to prices. The rules that this reform envisages (we stress, at the steady state) are not dissimilar from those proposed by the common reform (R3). Results are shown in figures 6.22-6.28.

Figure 6.24 shows the age distribution of exit probabilities. These are all shifted to older ages, both because we impose that people cannot retire before age 57 and because incentives are such that it is optimal to postpone retirement. The reduction in gross benefits is substantial at ages 50 to 60 


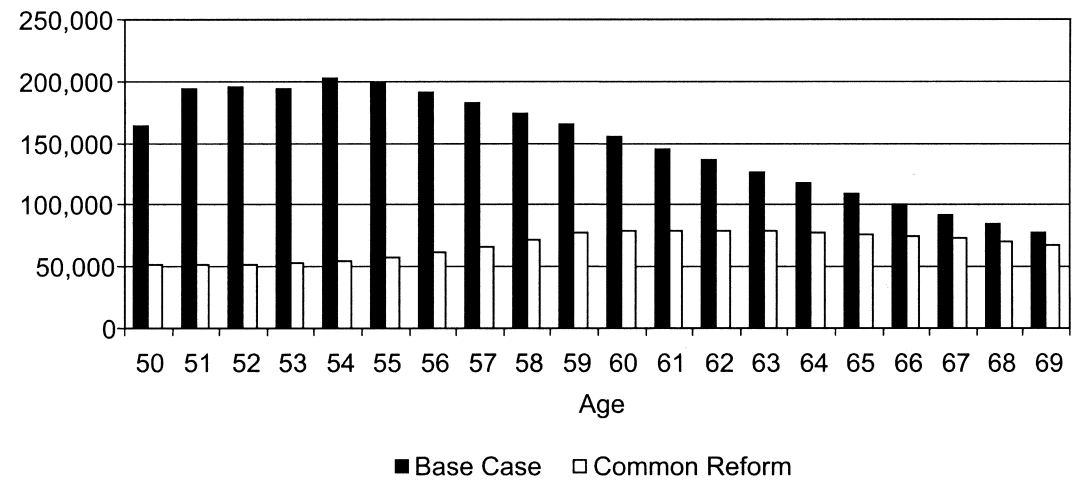

Fig. 6.22 Common Reform-Option value, SSW by age of labor force exit (OV age dummies)

Note: Values in euros of 2001.

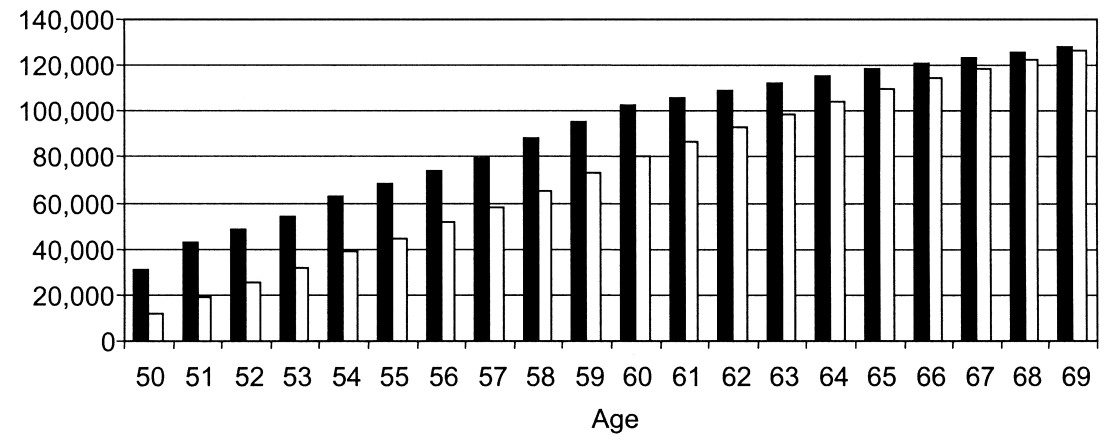

- Base Case $\quad$ C Common Reform

Fig. 6.23 Common Reform-Option value, taxes by age of labor force exit (OV age dummies)

Note: Values in euros of 2001.

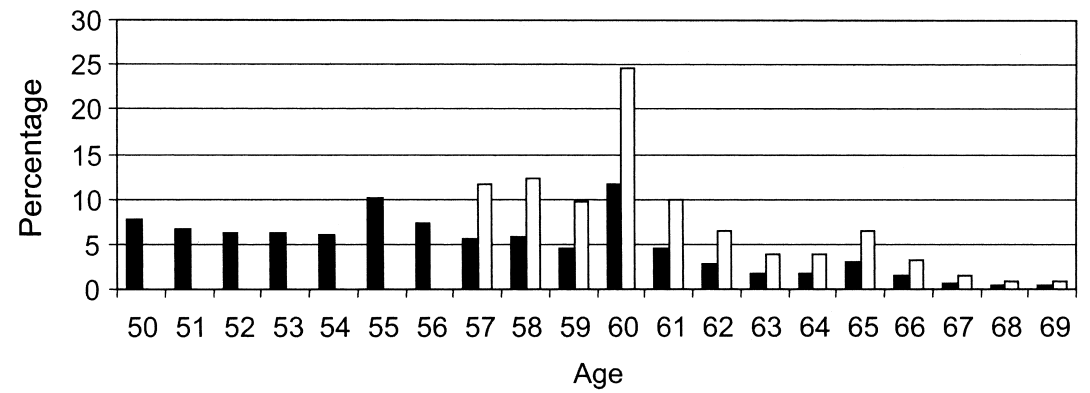

Base Case $\square$ Dini Modified

Fig. 6.24 1995 Reform (Dini Reform) — Option value, distribution by age of labor force exits ( $\mathrm{OV}$ age dummies)

Note: Values in percentage terms. 


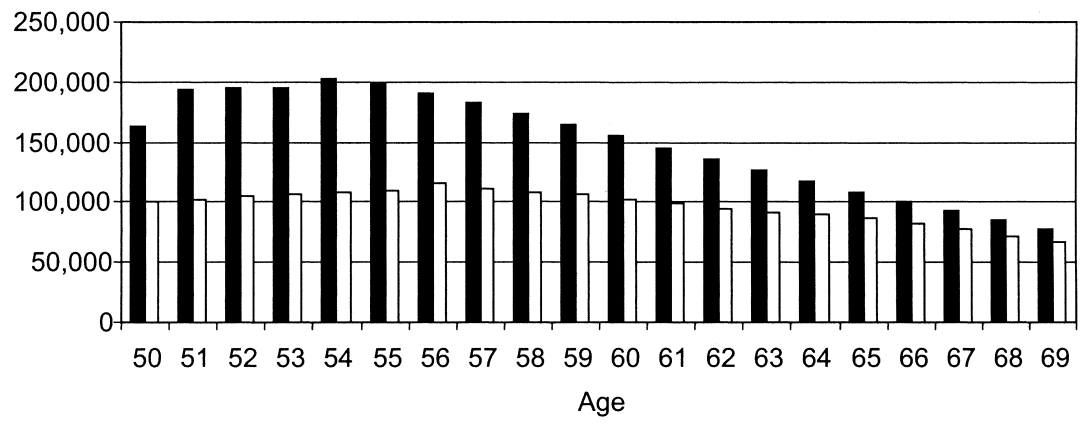

Base Case $\square$ Dini

Fig. 6.25 1995 Reform (Dini Reform)—Option value, SSW by age of labor force exit

Note: Values in euros of 2001.

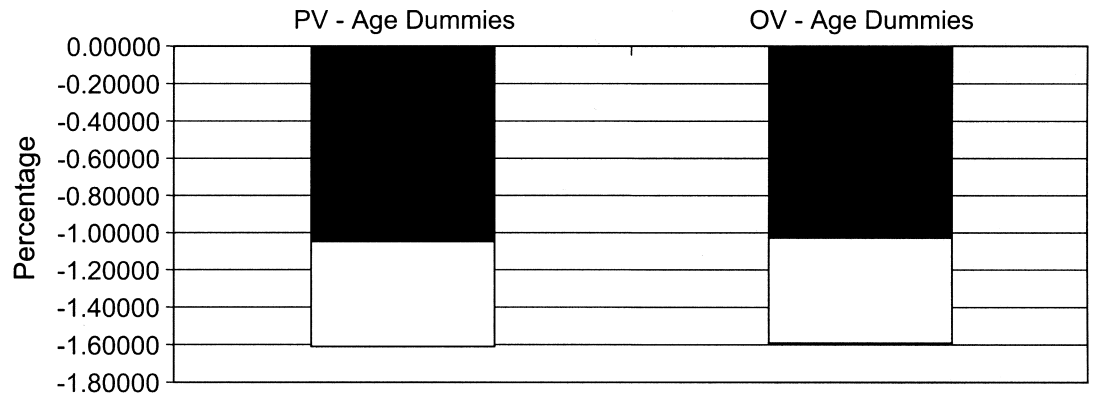

Mechanical Effect $\quad \square$ Fiscal Implications of the Behavioral Effect

Fig. 6.26 1995 Reform (Dini Reform) — Option value, fiscal implications of Dini Reform as a percentage of GDP

Note: Values in euros of 2001.

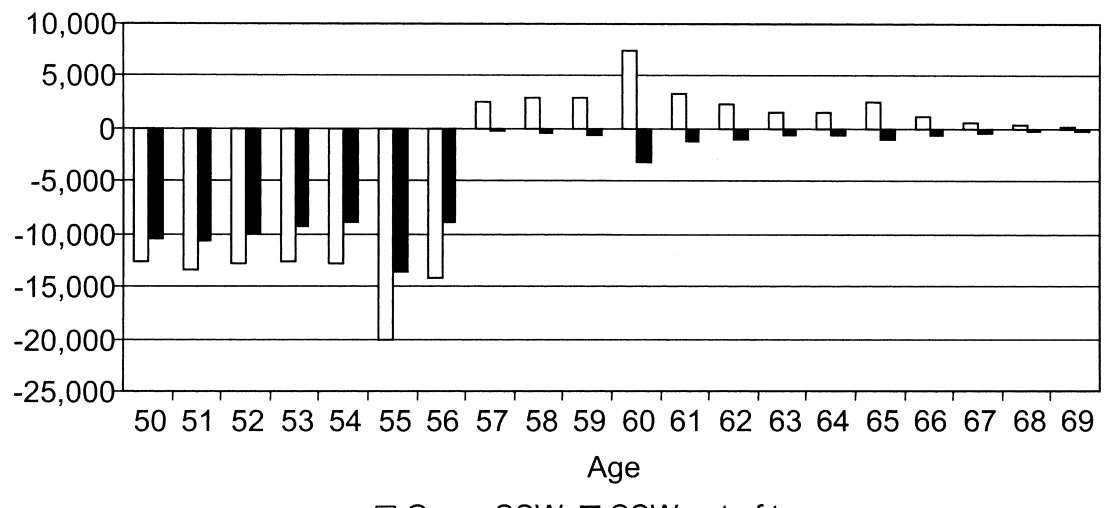

Fig. 6.27 1995 Reform (Dini Reform) — Option value, total effect by age of retirement (OV age dummies)

Note: Values in euros of 2001. 


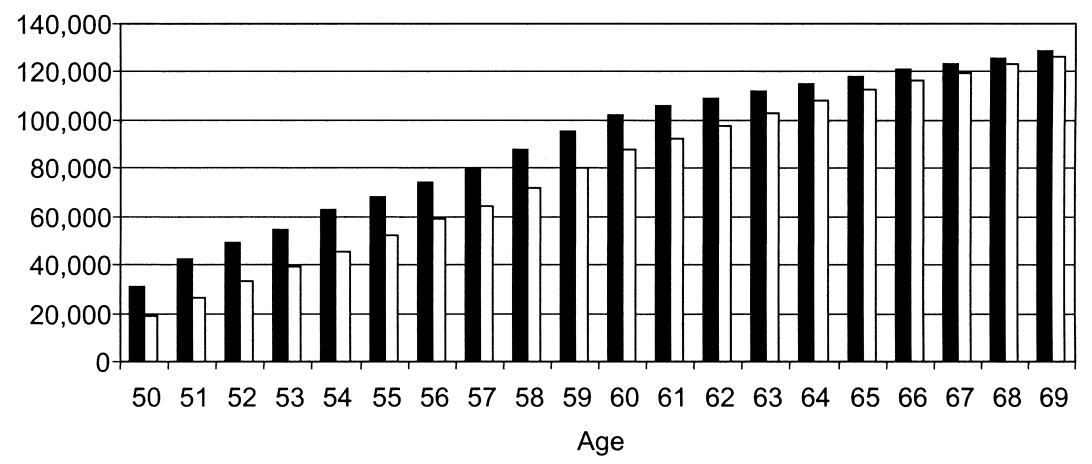

Base Case $\square$ Dini

Fig. 6.28 1995 Reform (Dini Reform) — Option value, taxes by age of labor force exit

Note: Values in euros of 2001.

Total fiscal impact of the Dini Reform

\begin{tabular}{|c|c|c|c|}
\hline & \multicolumn{2}{|c|}{ Present discounted value } & \multirow{2}{*}{$\begin{array}{c}\begin{array}{c}\text { Total change } \\
\text { relative to base }(\%)\end{array} \\
\text { Dini Reform }\end{array}$} \\
\hline & Base & Dini Reform & \\
\hline \multicolumn{4}{|c|}{ Peak value-Age dummies } \\
\hline Benefits & 168,016 & 98,072 & -41.63 \\
\hline \multicolumn{4}{|l|}{ Taxes } \\
\hline Payroll & 32,398 & 49,780 & 53.65 \\
\hline Income & 25,847 & 23,411 & -9.43 \\
\hline VAT & 16,879 & 15,026 & -10.98 \\
\hline Total & 75,124 & 88,217 & 17.43 \\
\hline \multicolumn{4}{|c|}{ Option value - Age dummies } \\
\hline Benefits & 166,778 & 97,522 & -41.53 \\
\hline \multicolumn{4}{|l|}{ Taxes } \\
\hline Payroll & 33,387 & 50,309 & 50.69 \\
\hline Income & 26,214 & 23,617 & -9.91 \\
\hline VAT & 16,949 & 15,054 & -11.18 \\
\hline Total & 76,549 & 88,980 & 16.24 \\
\hline
\end{tabular}

(figure 6.25). As a result, gross benefits are reduced by 41.53 percent and taxes increase by 16.24 percent (table 6.8). This is due both to a substantial mechanical effect ( -31.9 percent) and to a marked behavioral effect $(-17.1$ percent), which produce a net effect of -49 percent of benefits. The bulk of the losses is concentrated in the age group 50 to 56, while the older group experiences a gain in terms of gross benefits, largely offset by an increase in taxes (figure 6.27). In terms of private sector GDP, this reform would imply a gain for the government budget of approximately 1.6 percent. 
Distributional analysis of the Dini Reform model with age dummies

\begin{tabular}{|c|c|c|c|}
\hline & \multicolumn{2}{|c|}{ Present discounted value } & \multirow{2}{*}{$\begin{array}{l}\text { Change relative } \\
\text { to base PDV } \\
\text { Dini Reform }\end{array}$} \\
\hline & Base & Dini Reform & \\
\hline \multicolumn{4}{|c|}{ Quintile 5 (highest) } \\
\hline Benefits & 13,185 & 8,759 & $-4,426$ \\
\hline After-tax income & 11,839 & 8,013 & $-3,826$ \\
\hline \multicolumn{4}{|l|}{ Taxes } \\
\hline Payroll & 3,550 & 5,133 & 1,583 \\
\hline Income & 4,283 & 4,346 & 63 \\
\hline VAT & 1,348 & 1,298 & -51 \\
\hline Total & 9,181 & 1,323 & $-7,858$ \\
\hline Net change & & & 3,432 \\
\hline Change as $\%$ of base benefits & & & 26.03 \\
\hline \multicolumn{4}{|c|}{ Quintile 4} \\
\hline Benefits & 10,429 & 5,362 & $-5,067$ \\
\hline Taxes: Total & 4,474 & 1,226 & $-3,248$ \\
\hline Net change & & & $-1,820$ \\
\hline Change as $\%$ of base benefits & & & -17.45 \\
\hline \multicolumn{4}{|c|}{ Quintile 3} \\
\hline Benefits & 8,344 & 4,466 & $-3,879$ \\
\hline Taxes: Total & 2,840 & 591 & $-2,249$ \\
\hline Net change & & & $-1,629$ \\
\hline Change as $\%$ of base benefits & & & -19.53 \\
\hline \multicolumn{4}{|c|}{ Quintile 2} \\
\hline Benefits & 5,970 & 3,373 & $-2,597$ \\
\hline Taxes: Total & 1,785 & 258 & $-1,527$ \\
\hline Net change & & & $-1,070$ \\
\hline Change as $\%$ of base benefits & & & -17.92 \\
\hline \multicolumn{4}{|c|}{ Quintile 1 (lowest) } \\
\hline Benefits & 3,769 & 2,435 & $-1,334$ \\
\hline Taxes: Total & 876 & 74 & -802 \\
\hline Net change & & & -532 \\
\hline Change as $\%$ of base benefits & & & -14.12 \\
\hline
\end{tabular}

The distributional impact of the reform is somewhat perverse in our simulation, as the highest social security wealth quintile gains from the reform while all the rest of the cohort suffers a loss, particularly the median group (table 6.9).

\subsection{Conclusions}

The reform process that many advocate for the Italian social security system has rarely been analyzed with microdata. On the other hand, the few econometric studies available do not consider the total budgetary implications of the proposed pension reforms. In this chapter, we offer a novel 
approach to evaluating reforms that derives the entire range of fiscal implications by taking behavioral effects into account.

Our work builds on the econometric estimates in Brugiavini and Peracchi (2004), based on a longitudinal sample of private sector employees provided by the Italian Social Security Administration (INPS). A new release of the data allows us to employ a richer model, also briefly described in this chapter.

The simulation exercise considers three hypothetical reforms plus the actual reform introduced in Italy in 1995 (the so-called Dini Reform). These reforms are evaluated against a baseline represented by the pre-1992 system. The hypothetical reforms range from marginal variation of the status quo to an ideal system. The first regime change $(R 1)$ is a shift of three years in all retirement ages, the second $(R 2)$ proposes an actuarial adjustment to benefits such that early retirement is discouraged while providing incentives to delay exits. A reform common to all countries participating to the project $(R 3)$ allows us to evaluate the effects of a regime change that is quite radical in the Italian case, as it implies a sharp benefit cut, an actuarial adjustment, and a change in the indexation rules. Finally, a full application of the Dini Reform $(R 4)$ changes many features of the current system. In particular, it introduces a notionally defined contribution method of benefits computation. In several dimensions, this actual reform shows similarities with the hypothetical Common Reform.

The simulations are carried out by focusing on the cohorts of workers born in the years 1938, 1939, and 1940. For these workers, we construct measures of all the variables of interest, including projected probabilities of retirement under each policy regime.

Analyzing the three hypothetical reforms against the baseline, we find that even a modest change in the effective retirement age would imply nonnegligible effects. Measured as a percentage of prereform gross benefits, losses for the workers in our cohorts are approximately 17 percent. Grossing up to the population size of the cohorts considered, and measuring as a percentage of the Italian output, this change is equivalent to approximately 0.5 percent of the GDP produced in 2001 by the private sector. The losses for retirees represent savings for the government budget that come through a reduction in benefit outlays and increases in social security contributions, income tax revenue, and VAT revenue.

The Actuarial Reform and the Common Reform are particularly interesting for the Italian case. The former introduces in the baseline (pre-1993) regime an actuarial adjustment, leaving unaffected all other aspects of the social security system. This change has some effects on the age distribution of retirement rates, as workers tend to delay retirement. Coupled with the actual reduction of benefits that the reform envisages for younger retirees, we obtain a net total effect of -12.1 percent of baseline gross benefits. In terms of GDP, the revenue gains are of the order of 0.4 percentage points. 
The Common Reform reduces the probability of exit at younger ages and shifts the distribution of retirement rates toward older ages. Gross benefits are much lower at all ages, particularly at ages 50 to 60 . The total impact on gross benefits is huge, but due to a reduction in the total tax burden, the overall net effect is a loss to workers of 51.1 percent relative to the baseline case. This is almost completely explained by the mechanical effect, which swamps the small gain due to delayed retirement. The total effect is quite sizeable in the aggregate: fiscal authorities would gain approximately 1.6 percent of GDP.

Finally, the Dini Reform of 1995 also introduces radical changes in the Italian pension system. In our simulations, this reform is evaluated at its steady state. The age distribution of retirement rates is shifted toward older ages, both because workers cannot retire before age 57 and because incentives are such that it is optimal to postpone retirement. The reduction in gross benefits, leading to an almost uniform distribution of benefits under the new regime, is substantial at ages 50 to 60 . Overall, the net effect is a 49 percent benefit loss for workers in the chosen cohorts. If fully implemented in 2001, this reform would imply a gain for the government budget equal to about 1.6 percent of private sector GDP.

The general conclusion is that, in Italy, there is still room for reforms able to generate nonnegligible savings for the government budget. Some of these reforms would also have desirable properties in terms of redistribution between generations, and between rich and poor retirees. Further research is needed to assess the effects of these reforms for a larger number of cohorts and to analyze the distributional impact of the regime changes in several dimensions.

\section{Appendix}

\section{The Treatment of Taxes and Contributions}

We have made use of four different types of taxes. These are estimated for the years 1973 to 1996 (the period in which we observe the real labor force exit) and then projected twenty years forward.

First we use contributions (or payroll taxes) paid by both the employee and the employer. The source is INPS (www.inps.it/Doc/Professionista/ aliquote/aliquote.htm) for the years 1991 to 2000. For the years between 1973 and 1990 we refer to "Relazione Generale sulla Situazione Economica del Paese," published by Ministero della Programmazione Economica e del Tesoro. The contribution rate paid by employees increases every year, from 0.0635 of gross earnings in 1973 to 0.0889 in 1999. The rate paid by employers increases from 0.1345 to 0.2381 in 1999 . 
Next we use income taxes, both for earnings and for pensions. In Italy, there are several income brackets attracting different tax rates (see "Testo Unico delle Imposte sui Redditi"). From 1974 to 1982 we could count 32 income brackets, which we grouped into nine groups in order to compare with the legislation of the 1990s. We also modify the tax rates accordingly (these range from 10 percent to approximately 60 percent). In this dataset we have also included rates to calculate the deductions for employees and pensioners. There are different deduction values for every income bracket and for every year.

The third type of taxes are Value Added Taxes (VAT), which would be collected on expenditures. There are mainly four VAT tax rates, which apply to different goods and services. We create a basket of goods and services with a related price index. From this we infer an average VAT rate to be applied on expenditures. This has been changing every year: the order of magnitude is 0.09089 in 1982; 0.09521 in 1983; 0.10763 until 1993, and then it decreases slightly. As we only observe earnings in our data, we calculate the total value of this tax as a percentage of earnings, taking account of the average propensity to consume. This is approximately 70 percent of income, which is about 55 percent of earnings.

\section{References}

Barbi, E. 2001. Aggiornamento ed analisi delle caratteristiche strutturali dei coefficienti di trasformazione previsti dalla legge 335/1995. In Completezza e qualità delle informazioni statistische utilizzabili per la valutazione della spesa pensionistica, Rapporti di Ricerca, no. 1, ed. F. Peracchi, E. Barbi, A. Brugiavini, T. Tamborrini, and E. Viviano, 8-26. Rome: Presidenza del Consiglio dei Ministri, Commissione per la Garanzia dell'Informazione Statistica (CGIS).

Brugiavini, A. 1999. Social security and retirement in Italy. In Social security and retirement around the world, ed. J. Gruber and D. Wise, 181-237. Chicago: University of Chicago Press.

Brugiavini, A., and F. Peracchi. 2004. Micro-modeling of retirement behavior in Italy. In Social security programs and retirement around the world: Microestimation, ed. J. Gruber and D. A. Wise, 345-99. Chicago: University of Chicago Press.

Brugiavini, A., F. Peracchi, and D. Wise. 2003. Pensions and retirement incentives: A tale of three countries: Italy, Spain and the U.S.A. Giornale degli Economisti e Annali di Economia 61 (2): 131-70.

Fornero, E., and O. Castellino. 2001. La riforma del sistema previdenziale Italiano. Bologna: Il Mulino.

Franco, D. 2002. Italy: A never-ending pension reform. In Social security pension reform in Europe, ed. M. Feldstein and H. Siebert, 251-60. Chicago: University of Chicago Press.

Gruber, J., and D. A. Wise. 1999. Social security and retirement around the world. Chicago: University of Chicago Press. 
Gruber, J., and D. Wise. 2004. Social security programs and retirement around the world: Micro-estimation. Chicago: University of Chicago Press.

Ministero dell'Economia. 2001. Aggiornamento del modello di previsione del sistema pensionistico della RGS: le previsioni'00, June. Unpublished paper.

Rossi, N., A. Sorgato, and G. Toniolo. 1993. I conti economici italiani: Una ricostruzione statistica, 1890-1990. Rivista di Storia Economica 10:1-47. 
